NBER WORKING PAPER SERIES

\title{
ANALYZING COMPENSATION METHODS IN MANUFACTURING: PIECE RATES, TIME RATES, OR GAIN-SHARING?
}

\author{
Susan Helper \\ Morris M. Kleiner \\ Yingchun Wang \\ Working Paper 16540 \\ http://www.nber.org/papers/w16540
}

\author{
NATIONAL BUREAU OF ECONOMIC RESEARCH \\ 1050 Massachusetts Avenue \\ Cambridge, MA 02138 \\ November 2010
}

For their helpful comments, we thank Wei Chi, Colleen Manchester, Yijiang Wang, and participants in seminars at the University of Minnesota and the Labor and Employment Relations Association meetings The views expressed herein are those of the authors and do not necessarily reflect the views of the National Bureau of Economic Research.

NBER working papers are circulated for discussion and comment purposes. They have not been peerreviewed or been subject to the review by the NBER Board of Directors that accompanies official NBER publications.

(C) 2010 by Susan Helper, Morris M. Kleiner, and Yingchun Wang. All rights reserved. Short sections of text, not to exceed two paragraphs, may be quoted without explicit permission provided that full credit, including $\odot$ notice, is given to the source. 
Analyzing Compensation Methods in Manufacturing: Piece Rates, Time Rates, or Gain-Sharing? Susan Helper, Morris M. Kleiner, and Yingchun Wang

NBER Working Paper No. 16540

November 2010

JEL No. J3,J31,L1,L2,L23,L6

\begin{abstract}
$\underline{\text { ABSTRACT }}$
Economists have often argued that "pay for performance" is the optimal compensation scheme. However, use of the simplest form of pay for performance, the piece rate, has been in decline in manufacturing in recent decades. We show both theoretically and empirically that these changes are due to adoption of "modern manufacturing" in which firms produce a greater variety of products to a more demanding quality and delivery standard.

[

We further develop a theory of the type of compensation system appropriate for this kind of production, in which there is a high return to "multi-tasking", where the same workers perform both easy-to-observe and hard-to-observe tasks and to "just-in-time" production, which entails a high cost of holding inventory. [

We test these predictions using detailed monthly information on firm outcomes and employee surveys from four plants in two companies that adopted modern manufacturing methods and changed their method of compensation from piece rates to either time rates or value-added gain-sharing. We find that time rates and gain-sharing are associated with reduced employee performance on easy-to-observe tasks, enhanced performance on hard-to-observe tasks, and improved firm profitability. Our analysis shows the importance of distinguishing types of incentive pay: we find that modern manufacturing is consistent with either group incentive pay (such as gain-sharing), or no incentives (such as hourly pay), but inconsistent with individual incentive pay (piece rates).
\end{abstract}

Susan Helper

Weatherhead School of Management Case Western Reserve University

11119 Bellflower Rd

Cleveland, $\mathrm{OH}$ 44106-7235

and NBER

susan.helper@weatherhead.cwru.edu

Morris M. Kleiner

University of Minnesota

Humphrey Institute of Public Affairs

260 Humphrey Center

301 19th Street South

Minneapolis, MN 55455

and NBER

kleiner@umn.edu
Yingchun Wang

8 QMHUWWIRI $[+$ RXWRQ]' RZ QMRZ Q

One Main Street

Houston, Texas 77002

wangy@uhd.edu 


\section{Introduction}

Economists have often argued that "pay for performance" is the optimal compensation scheme (e.g., Lazear and Shaw, 2007, Shaw, 2009). However, use of the simplest form of pay for performance, the piece rate, has been in decline in manufacturing in recent decades. We show both theoretically and empirically that these changes are due to the adoption of "modern manufacturing" (Milgrom and Roberts, 1990), in which firms produce a greater variety of products to a more demanding quality and delivery standard.

The economic theory of optimal incentives suggests that changes in production environments should coincide with changes in the method of pay for workers (Lazear and Shaw, 2007). If workers produce one easy-to-monitor product and are supervised by an owner who both monitors and receives profits, the optimal incentive system is a piece rate (Seiler, 1984, Brown, 1990, Paarsch, and Shearer, 2000). Under this form of compensation, workers are paid based on the quantity and quality of the output produced. If markets are competitive, workers will receive their marginal product and owners will receive normal profits (Lazear, 2000, Halley, 2003).

However in the United States, use of piece rate systems has been systematically declining. In the later part of the $19^{\text {th }}$ century a majority of factory workers were paid piece rates, and about 30 percent of manufacturers used piece rate systems in the 1930s (Brown \& Philips, 1986). Yet by the 1980s only 14 percent of employees in manufacturing worked under piece rate systems (Jacobsen \& Skillman, 2004). By 2003, less than 5 percent of workers were paid under a piece rate compensation system (Schildkraut, 2003). In shoe manufacturing, for example, 90 percent of workers were paid by piece rates in the 1940s, but by the late 1990s, less than 25 
percent were paid by this method (Bureau of Labor Statistics, 1997) ${ }^{1}$. Other industrialized nations such as Britain have been experiencing similar declines in the use of piece rates in manufacturing (Marginson, 2010)

We suggest that the reason for the decline in use of piece rates is the introduction of manufacturing methods that emphasize quality, rapid introduction of new products, and "just-in time” production methods. These changes have a big effect on the optimal method of pay because they increase the return to

a) “multi-tasking” (Holmstrom and Milgrom, 1990), in which the same workers do both easy-to-observe tasks (such as production) and hard-to-observe tasks (such as process improvement) and

b) producing exact quantities of output (no more, no less).

In this paper, we model the impact of the changes of compensation method in such production environments. We consider the following methods of pay: piece rates, time rates, and gain sharing, in which workers receive time rates plus a (usually small) bonus linked to the productivity of the establishment or work group.

We also provide evidence from six plants belonging to two firms that changed from a piece rate method of pay to either time rates or gain sharing. Our empirical analysis examines how compensation influenced productivity, profitability, and the attitudes of the workers in these organizations.

Both our theory and evidence suggest that for firms with production processes with a high return to multi-tasking and to producing exact levels of output, time rate pay or time rates

\footnotetext{
${ }^{1}$ Our analysis differs from that of Shaw (2009), who writes, "Our knowledge of how to use HR practices evolves and improves over time. Thirty years ago, hourly pay was common; today, variable pay has been added.” We agree that group-based variable pay has been increasing (Osterman,2000), while individual-based incentives have been disappearing. Our paper shows that this distinction is critical: while group-based incentive pay is indeed compatible with modern production methods, individual incentives (piece rates) are not.
} 
with low-powered incentives are the optimal form of compensation. These findings may have implications for other industries, such as finance and health care, where firms have based pay on types of performance that are easily observable, even when important dimensions of performance are hard to observe and measure.

\section{Background, Theory and Model}

\section{A. Traditional manufacturing: mass production and large-batch production}

In the later part of the $19^{\text {th }}$ century a majority of factory workers were paid piece rates (Brown \& Philips, 1986). However, over the course of the $20^{\text {th }}$ century, many employers moved toward time rates. Some employers (such as Henry Ford) adopted "transfer lines," in which work was transferred between stations either by machines or by a moving conveyor (assembly line). In either case, time rates are more advantageous than piece rates. The reason is that managers can obtain high effort from workers on observable tasks by noticing where the inventory piles up between stations, ${ }^{2}$ without incurring the costs of piece rates we discuss below.

Many firms did not switch to transfer lines, however, because such lines placed severe constraints on the variety of products that could be produced, especially before the advent of innovations such as flexible automation (Best, 1990; Lazonick, 1991). Instead, many firms (including the two we study here) used batch production methods. For example, in the 1980s the firm we call "Small Parts" had a variety of products (mostly parts for cars or boats) for which there was continuing demand for an unchanging design. However, the products required operations on different machines, performed in different orders. Setting up fixed paths for work to travel would have made low effort in production more observable, but would have made the production process very inflexible. Therefore, managers put each person in charge of a machine

\footnotetext{
${ }^{2}$ Thus, workers can work together on assembly lines ("teamwork" in some definitions), yet still have observable individual contributions to total output (Lazonick, 1993, chapter 5).
} 
that could do several jobs (each with a negotiated rate), and encouraged workers to do each job quickly via piece rates. Since there was recurring demand for each product for a long time, management did not have to negotiate new piece rates very often ${ }^{3}$. At any one time the firm made an intermediate number of products that did not change very often—more than 1 or 2 , which would have made an assembly line pay off, and fewer than 50 products which would change in the next year, thereby requiring lots of renegotiation. Similarly, the shoe-maker we call Big Foot (BF) for decades had employees working on individually-paced machines being paid piece rates.

B. Modern manufacturing: quality, variety, and just-in-time production.

In the 1990s, both Small Parts and Big Foot changed numerous aspects of their operations strategy, moving toward a broader product line with frequent product introductions, greater attention to quality and efforts to minimize inventory.

Milgrom and Roberts (1995) call this cluster of policies “modern manufacturing”, and explain why these policies all changed at once:

"We have argued in this paper that this clustering [of policies] is no accident. Rather, it is a result of the adoption by profit-maximizing firms of a coherent business strategy that exploits complementarities, and the trend to adopt this strategy is the result of identifiable changes in technology and demand.”

In this paper, we extend the Milgrom and Roberts model to examine the impact on compensation methods of the changes in manufacturing that they and others describe. ${ }^{4}$

\footnotetext{
${ }^{3}$ As described below (also see Helper and Kleiner 2009), piece rates were negotiated with workers even though the firm was non-union. If rates were too low, workers objected to working on the new products. Management in principle had the right to assign workers to work on such products, but feared the loss of firm-specific human capital if workers quit.

${ }^{4}$ Others have noted similar changes in manufacturing strategy, and given them different names: "flexible specialization” (Piore and Sabel 1984), "lean manufacturing” (Womack, Jones, and Roos 1990). The clusters identified by the author above are broadly similar, yet the authors disagree about the causes of the change. Milgrom and Roberts focus on declining costs of computers and flexible automation as driving the change (because this new technology lowered the cost of product variety by reducing set-up costs). Piore and Sabel state that fragmentation of product demand (leading to greater benefits of product variety) was the initial cause, and Womack, Jones and Roos argue that the initial driver was Toyota's innovative efforts to adapt US production methods to 1950s Japan, in
} 
Figure 1 describes how the features of modern manufacturing affect the returns to different production strategies, and how these in turn affect the optimal compensation system (in particular, the efficacy of piece rates) ${ }^{5}$.

The first feature we examine is increased attention to product quality. A desired increase in product quality increases the return to effort on hard-to-observe tasks, such as suggestions for process improvement, and avoiding hard-to-detect shortcuts. Why is quality control a hard to observe task? While in principle, management could only pay for good pieces under piece rates, this is problematic in practice, for several reasons. First, if standards for quality are high, and affect workers' pay, management and workers will devote costly resources to allocating (and avoiding) blame for quality problems rather than seeking their root causes. Second, workers are less likely to make suggestions to improve the product that require teamwork or cross job boundaries, because this would involve particularly complex rate renegotiations, not to mention take time away from production, which costs the worker heavily in lost piece-rate income. If workers do not make good suggestions, it is hard for management to know if this was because potential improvements do not exist, or because workers were insufficiently motivated to make such suggestions.

Holmstrom and Milgrom (1991) point out that the multitask problem arises only if the two tasks are complementary. If they are not, then managers should design the observable tasks (e.g., production) to be done by one group of employees, and the unobservable tasks (e.g.,

which demand was fragmented and cash was scarce. In any case, as we show below, complementarity means that increased returns to one of these practices leads to increased returns for the others. So, for our purposes, it does not matter which practice was the driving force.

${ }^{5}$ Because the changes in production and in method of pay have complementary effects on firm performance, these practices will usually be adopted together, making it difficult to separately identify their impacts. Our goal instead is to explore the impact of these clusters of practices taken together. 
making improvements to production, fixing problems) to be done by another group with a different compensation scheme.

In older methods of production, observable and unobservable tasks were separated. Production workers focused on producing output, and were paid a piece rate. Quality was the responsibility of other workers, such as inspectors (who identified defective parts) and engineers (who attempted to design less defect-prone products and processes); these workers were paid time rates.

In contrast, proponents of “modern manufacturing” hold that multitask complementarities are significant. For example, while a worker is producing output, she is also observing the process and gaining a local knowledge available to engineers only at great cost. Thus, knowing how to do production gives a worker knowledge about how to improve the process (Womack, Jones, and Roos, 1990). However, piece rates incentivize workers to over perform on observable tasks such as production, and underperform on hard to observe tasks such as process improvement, as we show below.

The second feature of modern manufacturing described in Table 1 is increased product variety. ${ }^{6}$ Increased variety also yields increased payoff to production worker effort on hard-toobserve tasks, such as making suggestions on how to debug the production process for new products, yielding a quick ramp-up to full production speed. Piece rates are problematic because there are significant risks for both sides in establishing rates on new products. All else equal, the lower the rates per piece, the higher are profits and the lower are wages. If high-seniority workers are risk-averse and have the ability to choose which products they work on (as at Big

\footnotetext{
${ }^{6}$ In their model, Milgrom and Roberts distinguish between the number of products and product improvements, and find that the number of products is not necessarily complementary to other features of modern manufacturing, because if there is a constant rate of redesign per product, having more products increases cost. Since both a new product and a redesigned product usually require a new piece rate, we lump them together under the heading "product variety", a feature which is complementary with other characteristics of modern manufacturing.
} 
Foot), experienced workers will avoid working on new products, depriving the firm of precisely those workers who would be most efficient at de-bugging the new process (Freeman and Kleiner, 2005). As Coase (1937) pointed out, establishing prices is a significant cost of using markets. As the frequency of product change increases, the fixed cost of haggling over the rate is spread out over fewer units, making a piece-rate system increasingly costly.

The third feature we examine is just-in-time production (JIT). Proponents of JIT argue that holding inventory is very costly, due not just to product carrying costs, but also to costs of obsolescence and the impact of long lead times on quality improvement activities. (That is, if a long time passes between when a product is made and the discovery that it is defective, it will be harder to determine conditions under which it was made that might have led to the defect (e.g., the day was hot, the worker running the machine was inexperienced) (Womack, Jones and Roos, 1990). JIT is complementary not only to quality, but also to product variety, in that short set-up times allow a firm to produce a wider variety of products without excessive downtime or inventory carrying costs. Thus, the philosophy of JIT is to produce exactly the quantity demanded, meaning that there is a low return to the extra production incentivized by piece rates. JIT also increases the return to multi-tasking (since low inventory increases the return to speedy problem-solving).

To summarize, implementing modern manufacturing practices makes piece rates a less desirable form of compensation in two ways. First, modern manufacturing increases the return to multi-tasking (having the same workers perform both tasks whose output is hard to observe and tasks whose output is easy to observe). Specifically, workers' responsibilities expand from simple physical execution of work in manufacturing to activities such as planning, decisionmaking, teamwork, and problem solving (Shaw, Gupta, and Delery, 2001; Snell and Dean, 1994). 
Performance on these tasks is difficult to observe. As we show below, piece rates lead to the crowding out of effort on such tasks. Second, the extra effort on observable tasks (like production) that piece rates produce has low (sometimes negative) value in modern manufacturing, because of the high cost assigned to carrying inventory.

\section{Model of multi-tasking and just-in-time}

In order to analyze the situations discussed in the empirical section below, it is useful to formally model the effects of switching from piece-rates to time-rates (Big Foot) and from piecerates to gain-sharing (Small Parts) ${ }^{7}$. Proofs of all propositions are provided in the appendix.

Define $e$ to be the performance level of the hard-to-observe tasks and $q$ to be the quantity of output produced. $e$ and $q$ are determined by both employee effort $\left(t_{e}\right.$ and $\left.t_{q}\right)$ and employee ability ( $A_{e}$ and $A_{q}$ ). Naturally, $\frac{\partial e}{\partial t_{e}}>0 \frac{\partial e}{\partial A_{e}}>0 \frac{\partial q}{\partial t_{q}}>0 \frac{\partial q}{\partial A_{q}}>0$. The firms' profit functions are given by

$$
\Pi=B(e, q)-L
$$

where $B$ is production technology and $L$ is labor costs. Naturally, $B_{1}>0$. By contrast, $B_{2}$ varies depending on whether $q$ exceeds or falls short of the optimal production quantities, $\hat{q}$. Specifically, $B_{22}<0$, and $\Pi$ is maximized when the quantity produced matches the optimal production quantity, that is, $q=\hat{q}$. The reason behind this specification is that producing exactly the optimal quantity is highly important in modern manufacturing. Both over-production and under-production are costly, because holding very little inventory (just-in-time production) is highly valued (i.e. $\Pi(\hat{q})>\prod(q)$ for $\forall q \neq \hat{q}$. On the one hand, if the quantity produced exceeds

\footnotetext{
${ }^{7}$ Consistent with the practice at most firms (and in contrast to Thiele, 2010), we assume the firms are constrained to offer the same contract to all production workers.
} 
the optimal quantity, $\hat{q}$, the firm incurs costs associated with holding inventory and the uncertainty of being able to sell the inventory because of frequent product design changes. Thus, when $q>\hat{q}, B_{2}$ becomes smaller. And profit becomes negative, when $q$ exceeds $\hat{q}$ by large amounts. On the other hand, modern manufacturers also value meeting clients' needs quickly. If output falls short of the optimal quantity, it could lead to client dissatisfaction. Thus, when $q<\hat{q}$, it pays to produce more quickly ( $B_{2}>0$ ).

Under piece rates, employees' utility functions are $U_{p}=p(e)\left(\beta^{p}+\alpha q\right)-D\left(t_{e}, t_{q}\right)$, with $D$ being the monetary value of the disutility associated with additional effort, $\beta^{p}$ being the baseline salary under piece rates, $\alpha$ being the piece-rate for each unit produced, and $p(e)$ being the probability of keeping the job based on a worker's performance on hard-to-observe tasks, with the performance $e$ being determined by effort, $t_{e}$, and ability, $A_{e}$. Under gain-sharing, employees' utility functions become $U_{g}=p(e)\left(\beta+\lambda \frac{B(e, q)}{N}\right)-D\left(t_{e}, t_{q}\right)$, with $\beta$ being the baseline salary, $N$ being the number of employees included in the group bonus, and $\lambda$ being the income percentage that the employer agrees to share with the workers ex ante. Under time rates, employees' utility functions become $U_{t}=p(e) \beta-D\left(t_{e}, t_{q}\right)$.

Proposition 1: When a firm switches from piece rates to gain-sharing or time-rates, the gap between optimal output and actual output, $|q-\hat{q}|$, is smaller.

Time-rates and gain-sharing pay employees based on obedience rather than on production quantity. If the employees keep the pace that the firms determine, they are paid. If not, they risk being fired. By contrast, under piece-rates, to make employees produce exactly the optimal quantities, employers need to set piece-rates such that the marginal benefit to the worker just equals her marginal disutility when she produces the optimal output. To the extent that optimal 
output and product designs change frequently, and employers lack information regarding employee utility functions, piece rates lead actual output to deviate from optimal output.

Proposition 2. When firms switch from piece rates to gain sharing or time rates, effort devoted to hard-to-observe tasks, $t_{e}$, increases.

The intuition behind Proposition 2 is that since workers' effort is limited, the more effort they devote to observable tasks, the less effort they are able to devote to hard-to-observe tasks.

That is, $\frac{\partial t_{q}}{\partial t_{e}}<0$. Gain-sharing rewards employees for doing hard-to-observe tasks by sharing the gains, so workers have more incentive to devote effort to such tasks. Although time-rates do not reward employees for effort devoted to hard-to-observe tasks, the firm could still instruct the workers to do some hard-to-observe tasks or risk being fired, and since unlike piece rates workers are not rewarded for producing more output, they will follow the firm's instruction and devote more effort to the hard-to-observe task than under piece-rates, by the amount $-\alpha \frac{\partial t_{q}}{\partial t_{e}}$.

Proposition 3. When the firms switch from piece rates to gain sharing or time rates, the average ability of the workforce to produce higher quantity of output, $A_{q}$, decreases. When a firm switches from piece rates to gain sharing, the average ability of the workforce on hard-to-observe tasks, $A_{e}$, increases. When a firm switches from piecerates to time-rates, the average ability of the workforce on hard-to-observe tasks, $A_{e}$, does not change.

The intuition behind this proposition is that the average ability of a firm's employees to do observable tasks decreases, because gain-sharing and time-rates do not reward employees for producing large quantities. Since gain-sharing rewards employees for their performance on hard- 
to-observe tasks, workers with greater ability to perform these tasks are attracted to the firm. Workers on time-rates do not get extra pay for performing well on these tasks, so employees' ability to do hard-to-observe tasks will not change if a firm switches from time- to piece-rates.

Proposition 4 Batch manufacturing with piece rates generates more production than does modern manufacturing with time rates or gain sharing.

The intuition behind this proposition is that excessive production volume makes profits drop more quickly for modern manufacturers than for batch manufacturers, so the optimal production volume will be larger for batch manufactures than for modern manufactures.

Proposition 5: If Just-In-Time and hard-to-observe tasks are valuable to a firm, when the firm switches from piece rates to gain-sharing or time-rates, the expected benefits increase. That is, $E\left[B_{t}^{*}\left(e^{t}, \hat{q}\right)\right]-E\left[B_{p}^{*}\left(e^{p}, \tilde{q}\right)\right]>0, E\left[B_{g}^{*}\left(e^{g}, \hat{q}\right)\right]-E\left[B_{p}^{*}\left(e^{p}, \tilde{q}\right)\right]>0$.

This proposition is derived from Proposition 1 to Proposition 3. Proposition 1 states that time-rates and gain-sharing are better at making employees meet production targets than are piece-rates. The possible excessive or insufficient production volume due to piece-rates is very expensive for modern manufacturers. In addition, Propositions 2 and 3 suggest that employee performance of hard-to-observe tasks, determined by abilities and effort, increases after switches from piece-rates to gain-sharing or time rates. Thus, with hard-to-observe task performance and Just-In-Time being valuable to modern manufactures, the production benefit function's value will increase after switching away from piece rates.

Proposition 6: When firms switch from piece rates to gain-sharing or time-rates, their labor costs remain the same or decrease.

Under piece-rates, employers set the rate according to agents' marginal monetary value of the disutility of producing the employer's desired amount of output. That is, if the employer 
wants $\hat{q}$ amount of output, she will set the rate as $\alpha=D_{2}\left(\hat{t}_{e}, \hat{t}_{q}\right)$. So the total pay under piece-rate is $L_{p}=D_{2}\left(\hat{t}_{e}, \hat{t}_{q}\right) \hat{q}$. But under time-rates and gain-sharing, to minimize costs, employers will set the labor cost as about equivalent with the agent's monetary value of the total disutility of producing $\hat{q}$. So the labor cost is $L_{t}=L_{g}=D\left(\hat{t}_{e}, \hat{t}_{q}\right)$.

The above rationale indicates that labor costs of time-rates or gain-sharing are not larger than that of piece-rates, because time-rates and gain-sharing are determined by worker's total disutility, while piece rates are determined by worker's marginal disutility, which is an increasing function of the amount of output. For example, suppose an agent's disutility of producing the first piece of output is worth one dollar, and the disutility of producing the second piece is worth more, say two dollars. To make the worker produce two pieces, managers using time-rates and gain-sharing need to pay the agent only $1+2=3$ dollars, but those using piece-rates will need to pay the worker 2 dollars per piece, for a total of $2 * 2=4$ dollars. The rent the worker gains from time rates and gain sharing is 0 , but the worker's rent is strictly larger than zero, one dollar in this example, under piece-rates.

Proposition 7: If Just-In-Time and hard-to-observe tasks are valuable to a firm, when firms switch from piece-rates to gain-sharing or time-rates, profits increase.

Profits are determined by benefits and labor costs. According to Proposition 5, if JIT and hard-to-observe tasks are valuable to a firm, when the firm switches from piece rates to gainsharing or time-rates, the expected benefits increase $E\left[B_{t}^{*}\left(e^{t}, \hat{q}\right)\right]-E\left[B_{p}^{*}\left(e^{p}, \tilde{q}\right)\right]>0$, $E\left[B_{g}^{*}\left(e^{g}, \hat{q}\right)\right]-E\left[B_{p}^{*}\left(e^{p}, \tilde{q}\right)\right]>0$. And according to Proposition 6, labor costs will not decrease when firms switches from piece rates to time rates, $L^{p} \geq L^{g}$ and $L^{p} \geq L^{t}$. Thus, it is straight 
forward to conclude that if JIT and hard-to-observe tasks are valuable, profits will increase after switching away from piece-rates $E\left(\Pi_{t}^{*}-\Pi_{p}^{*}\right)>0$ and $E\left(\Pi_{g}^{*}-\Pi_{p}^{*}\right)>0$.

\section{Empirical Analysis}

\section{Data Collection and Methods}

In collecting our data, our method was consistent with the 5 steps of the "Insider Econometrics” approach described by Shaw (2009, p.615). First, we conducted multiple plant visits. At Big Foot we visited at least a dozen times between 1996 and 1998, and talked with at least 100 people, including top management, union presidents, and many workers on the assembly line. For Small Parts, we visited its Massachusetts plants in 1995, 1998, 2000, and 2002. We also visited the Ohio and Florida plants each 3 times in 2002 and the UK plant in 2002 and 2003. At each visit we spoke with managers and toured the plant. In 2002, we conducted focus groups in each of these plants with workers (without management present). (See Freeman and Kleiner 2005 and Helper and Kleiner 2009 for more detail). Second, as a result of our plant visits, we identified the object of study as the impact on performance of changing methods of compensation. We treat the change in method of pay as exogenous to the workers, and identify variation in response based on worker ability and timing of the change in incentive systems (similar to Franceschelli, et al, 2010). Management did not implement gain-sharing in all of its plants at once. We suggest that the implementation process can be thought of as a quasi-natural experiment that can allow us to estimate the impacts of gain-sharing on both productivity and worker satisfaction. Third, we obtained detailed data from both companies, on financial reporting of what happened before, during, and after the change in the method of pay. Fourth, we used this data to test the predictions in our model. Fifth, we collected additional information from the workers themselves. At Big Foot, management gave us access to worker satisfaction surveys 
conducted before and after the change in the method of pay. At Small Parts, we conducted anonymous surveys of employee attitudes. Management allowed us to conduct these surveys during work time (workers went to a separate training room where no managers were present); the response rates exceeded $90 \%$ in each plant. We also presented our findings to the management of each plant, and learned from their responses.

In this section, we use our data to test predictions from the models specified above. ${ }^{8}$ The two firms in our sample consisted of one with labor-intensive products (shoes) and one with capital-intensive products (auto parts). Figure 1 panel A, gives the time line for the change from the piece rate to the time rate method of pay for Big Foot, $(\mathrm{BF})$ the labor-intensive firm in our analysis. In panel B we show the implementation of the policies for Small Parts using the same metrics.

The BF Shoe Company produces men's work shoes and sports boots in two unionized plants in a small mid-western city. The firm sells much of its product through its own retail outlets, which makes it sensitive to service at the point of purchase and direct consumer response to its products. However, in 2003 the company agreed with Sears to sell its men's work boots in all Sears retail outlets in the U.S., and it has agreements with national and international companies like J. Crew, to widely market its shoe and boot products.

In the mid 1980s the firm identified several problems that risked its survival in the face of foreign competition that was influencing the whole industry. The firm faced an inflexible production process; a huge work in-process and storage expenses and a demoralized piece rate compensation system. Consultants hired by the firm recommended that the firm try to create a niche market and introduce teamwork and continuous flow methods of production that required

\footnotetext{
${ }^{8}$ Both firms in our analysis agreed to let us use confidential internal documents if we did not use the name of the firm in our publications. Replication is allowed if a nondisclosure agreement is signed.
} 
employees to know many different tasks, warning that unless the firm lowered its costs, most of which were labor costs, it was unlikely to survive. Management thought that the company’s piece rate system was a barrier to making the necessary changes in production. The union was willing to go along with these policies so that the firm could remain viable.

The system of production made it difficult to introduce more styles and produce the higher quality products that offered a chance of survival in the face of low wage foreign competition. BF introduced a continuous flow mode of manufacturing (CFM) and changed from a piece rate to a time rate mode of compensation. The firm developed many new lines of shoes based on market demand, a modular form of production in which workers were cross-trained to cut days in-process, used a just-in time method of supplying materials to the lines, and thus was able to deliver "hot sellers" in a more rapid manner. The firm began to implement the new process in April 1990 in one factory, but it took roughly two and one-half years before all the plant's lines shifted to the continuous flow mode.

Making the transformation was difficult. Many supervisors did not support the CFM initiative and some actively worked against it because it meant a reduction in supervisory and inspection jobs. In fact, the firm eliminated six intermediate inspector jobs in each plant when it went to Continuous Flow Manufacturing. Thirty-three percent of the company’s supervisors and a number of senior managers took early retirement. Many production workers feared the loss of seniority, job rights, and reduced pay. Big Foot negotiated a lower hourly wage system for new hires but agreed to "red circle" the wages of all current production workers. That is, the firm would base current workers’ new hourly wage on their piece rate earnings in the future based on output for the 26 weeks previous to their department's shift to CFM. 
The firm had other problems in making the transition to continuous flow manufacturing. Failing to anticipate that productivity would fall sharply with the move to time rates, management had to schedule its production workers for as much as 10 hours'overtime work per week. On the other hand, following the transition in managerial policies, there was a dramatic drop in union grievances and in worker compensation costs. And BF increased the number of shoe styles from 106 in 1985 to 187 in 1996, more than doubling the number of new styles introduced per year from six during the piece rate regime to 13 in the time rate regime. From 1990 to 1997 , the percentage of shoe sales due to the top 10 styles dropped by $20 \%$ as new styles took a larger part of sales. Thus, by the end of the 1990s, Big Foot's managerial operations and pay for workers were different than at the outset of the decade. Labor costs were considerably lower. Thus the impact of Big Foot's change in compensation policy cannot be determined in isolation from the firm's other policies.

The other firm in our sample, Small Parts (SP), produces switches and actuators for firms in the auto industry. SP initially was a low-volume operation where quality requirements were not high, and where designs were generally dictated by the customer and did not change often. The older jobs were individually paced, and consisted of a single worker sitting at a machine. She would add one or more pieces to a small assembly and then press a button or foot pedal to fasten the piece via welding or crimping. She would then place the partially-completed product in a box; when the box was full, material handlers would move it to workers who would do the next stage. During our 1995 visit we watched several of these piece-rate workers, and were impressed by the workers' speed and intensity of focus.

In 1987, the firm began a major change in its product market strategy, and by the late 1990s it designed almost all of its own products (which are complex assemblies of plastic and 
electronic parts) and modified them frequently (50 in a typical year under the new strategy), rather than producing individual electronic components to customer blueprints. The company also increased its quality levels and reduced its inventory..These changes were common in the industry, and resulted from pressure from the firm's major customers, such as Ford and General Motors.

As a result of these product-market changes, the firm introduced changes in its operations. Management gradually brought in more automated assembly, eliminating individually-paced jobs. Instead, 6-8 workers sat around a circular work cell. Some stations were completely automated; at most stations a worker assisted the machine in assembling the part. When the part was finished, it would be moved (automatically or manually) to the next station. At the last station, the operator would pack the fully-completed part into a box to be shipped directly to the customer. The cell was paced by the slowest worker. At many of the cells, a lighted overhead sign kept track of the pieces made, and compared it to the pieces that should be made to meet the day's quota. Since there was no buffer between operators, inventory in the cells was dramatically lower (and lead times faster) than under piece rates.

By 2000, these assembly jobs employed the bulk of the work force in a highly capitalintensive method of production (Helper \& Kleiner, 2009). Labor costs were less than 10 percent of total production costs. The move in this firm was to modern manufacturing from batch production. The firm's new strategy was not consistent with SP's existing pay practices, which involved piece rates for operators and assemblers. As our theory suggests, piece rates led to problems with hard to observe tasks such as minimizing inventory, difficulty in changing to new products, and problems in encouraging teamwork. A particular problem was new product introduction. As SP's controller put it in a document she wrote for us in 2000, 
"New product development became a hurdle with the piecework system. Employees did not want to work on new product [because they would have to learn a new job, with the risk of lower pay while they figured out shortcuts]... There were no good standards for new product and there was no way to introduce new products unless we wanted to throw loose rates on them. This restricted us from doing new products."

As this quote illustrates, setting the rate on a new product took a long time and was fraught with conflict and risk for both parties, even in a nonunion setting such as SP.

SP Managers were concerned that time rates alone would not provide enough incentive to avoid wasteful inventory, prevent defects, or promote incremental improvement. As a result, the firm implemented a gain-sharing method of pay. The principle behind the value-added gainsharing program was to give workers as a group a stake in their plant's performance. The details of the plan changed over the years; initially, the size of the bonus pool was a function only of factors that management felt workers could influence: productivity increases, defect rates, and customer satisfaction. In the plants formerly on piece rates, most, production workers’ compensation fell significantly (though workers' reported effort also fell); in some former timerate plants compensation increased slightly. We present information on the dates of the movement away from piece rates and the introduction of the value-added gain sharing plan (VAG) in Figure 2 in panel B.

\section{Empirical Results}

In Table 1 we show summary statistics for the two firms in our sample. Our efforts to isolate the impact of gain sharing on productivity and satisfaction involve two types of tests. We examine the direct impact of the transformation on performance, using measures of productivity, costs, and profitability. Next, we measure the impact of the changes away from piece rates on employee attitudes toward performing hard-to-observe tasks at work.

Our basic models for estimation are of the following form: 
(A) $Q=f\left(K\right.$, Change, $\left.X^{n}, \varepsilon\right)$, where

$Q$ is productivity as measured by output or value added per worker,

Change is 0 for each month until the VAG or time rate program is introduced in that plant, and 1 afterward, $X$ is a set of controls for plant and individual characteristics, and $\varepsilon$ is the error term, with the usual ordinary least squares (OLS) assumptions on its structure.

In table 2, we estimate the impact of the switch away from piece rates on performance for both observable tasks (production) and hard-to-observe tasks (minimizing material costs). In panel A, we look at the impact for BF, controlling for 1) the transition period during which some but not all lines, had changed away from piece rates ("transition effect”), 2) the 26-week period during which employees could lock in a future time wage that depended on their piece-rate earnings during this period, an arrangement which created a powerful incentive for BF workers to work very hard during the period ("full effort effect"). ${ }^{9}$ We control for headcount, and also for time trend. We use material costs as a proxy for firms' success in incentivizing workers to perform hard to observe tasks. Our rationale is that the main ways to reduce material costs for a given amount of output are to improve quality and reduce inventory—both hard to observe activities, as we argued above.

In Panel B, we look at the same outcomes for SP. Our control variables are slightly different, as SP moved away from piece rates without a transition or 'full effort" period. In this table we include data only at the Boston plant, which is the only SP plant for which we have data before and after a move from piece rates to VAG. Our measure of productivity for SP is Value

\footnotetext{
${ }^{9}$ The dummy variable used to proxy for full effort isolates the period when the firm told workers that their productivity would determine pay for the duration of their employment; the implication is that under normal piece rates, productivity is below the productivity that workers reach by giving their full effort. Our ability to talk to managers and workers in each plant allowed us to identify the dates of the implementation of the transition and full effort periods. (Helper, 2000).
} 
Added $=$ Net Sales - Material Cost - Labor Cost. We also include production worker headcount, a monthly time trend.

Our estimates in Table 2, column 1, show that the coefficient on "change”, the variable capturing the move away from piece rates, is negative and significant in each of the productivity regressions. That is, overall output per person declined in both companies after the move away from piece rates. This result is consistent with our Proposition 4, that a move away from piece rates should lead to reduced performance on observable tasks. The result is also consistent with previous work on piece rates that examines only performance on observable tasks, such as Lazear and Franceschelli et al (2010). However, consistent with our multitask model; our data suggests that effort on hard-to-observe tasks increased. For example, material use declined; this suggests workers worked harder to minimize waste. In contrast, under piece rates, workers want to have as much material as possible available in order to produce additional units of output and maximize pay ${ }^{10}$.

Data from BF in Table 3 allow us to analyze Proposition 1, that planned output is closer to actual output when the firm moves away from piece rates. ${ }^{11}$ Planned output was estimated on a monthly basis by the engineers, with input from the sales force usually one year in advance. Using Equation (A), we examine the difference in planned output relative to actual output, before and after the change to time rates. The focal independent variable "change" is coded as 0 before switching from time rates and 1 after the changes. Similar to Table 2, we also controlled for total headcount, plant fixed effects, transition effect, and full effort effect in the estimation. We find that the transition to time rates was associated with a significant reduction in the gap between

\footnotetext{
${ }^{10}$ Note that although it is possible for the econometrician (and thus also the manager) to measure material costs in aggregate, that does not mean it is possible to construct an individual incentive to minimize material costs. For example, if extra material is used due to poor quality, there may be fights about whose fault the defect was. Alternatively, teamwork may be necessary to identify causes and propose solutions that lead to reduced scrap rates. ${ }^{11}$ Unfortunately, no such metric existed for SP.
} 
actual production and planned production, which allowed the firm to better meet its production targets. The data in Appendix B also shows that planned production volume declined after the change to time rates.

In Table 4 we show the determinants of workers' self-reported productivity and effort on hard-to-observe tasks. The analysis examines Proposition 3, which analyzes the selection effects of the transformation away from piece rates. Our basic model is :

(B) Coop $=f(\mathrm{VAG}, X, \varepsilon)$,

where employee attitudes toward cooperation with management goals ( Coop) is a function of whether the employee was hired after the implementation of value added gain sharing $(V A G)$ and plant characteristics $X$, and the $\varepsilon$ is the error term.

As measures of employee attitudes, we asked workers about meeting production targets, teamwork, suggestions, and overall satisfaction. We used a standard survey instrument, the Minnesota Satisfaction Survey (MSS) to examine employee satisfaction. The MSS has been used by industrial psychologists for more than 50 years to gauge employee satisfaction in American industry. The questions were of a Likert-type 5-point scale. We also asked the employees about their tenure with the company, type of job, and pay policies.

At the Boston plant, we were able to gather more detailed information on the characteristics of employees. A high percentage of the employees were immigrants from Vietnam and Cape Verde, and were not proficient in English. Consequently, we translated our questionnaire into Vietnamese and Portuguese; ${ }^{12}$ respondents chose the language in which they wanted to take the survey. Thus, we are able to differentiate individuals in the plant by their degree of assimilation to English.

\footnotetext{
${ }^{12}$ The Cape Verdeans spoke several dialects of Portuguese.
} 
The estimates are shown in Table 4 for SP, and although the results are not significant, the coefficients' directions are consistent with Proposition 3, that a transformation in the method of pay leads to the selection of workers with different characteristics, consistent with Lazear (2000). ${ }^{13}$ For example, workers hired after the transition occurred at their plant perceive themselves as being less productive, which is consistent with the findings in Table 2 that show productivity going down in SP following the transformation, and with Proposition 4, which shows that part of the reason for the productivity decline is that new workers are less able to perform easy to observe tasks. By contrast, the effects on teamwork, suggestions, and overall satisfaction are all positive although not precisely estimated. The estimates are consistent with Proposition 3, that new workers will have higher aptitude for teamwork and unobservable tasks relative to employees that were hired during the piece-rate era. Since satisfaction is closely linked in the human resource literature to turnover and other measures of firm performance, maintaining satisfaction when large changes occur in the firm is an important concern for employers (Judge, Thoresen, Bono, \& Patton, 2001).

As both Tables 3 and 4 show, the transition away from piece rates significantly improved the ability of the firm to hit its target production rather than just produce more units.

Tables 5 shows a test of Proposition 6 that labor should be reduced or remain the same when the transition occurs away from piece rates. The results for both firms are consistent with the prediction. These results suggest that the wage-effort bargain for production workers in these two plants shifted from a focus on a large amount of output at high total effort to providing more

\footnotetext{
${ }^{13}$ In Appendix Table, we also show the overall satisfaction changes in BF before, during, and after the change to time rates. The results show initial high levels of satisfaction, and then a decline as the firm changed, and then a return to a level similar to that which occurred prior to the change (the last measure was taken by another firm which used a different survey instrument and measure of satisfaction).
} 
hard-to-observe input and working together to produce what was required at a point in time, with lower total effort required.

Finally, Figure 3 and Table 6 tests Proposition 7 on profitability for both firms separately and together with controls for firm fixed effects. Figure 3 shows the before and after changes in compensation and profitability in both BF and SP. In both cases there is a trend upward following the transformation. In the left part of panel A, we show the influence of the change in method of pay on profitability at BF. The results show that the change enhanced profitability at BF by a statistically significant 18 percent. In the right part of panel A, we show only the results for the Boston plant of SP, which moved from piece rates to gain sharing. This plant most closely resembles BF. Consistent with our other findings we show a significant increase in profits of about 21 percent as a result of the change to gain-sharing from piece rates.

Next, in order to provide a sensitivity analysis we included all of the plants of Small Parts to show the influence of being in either a gain-sharing or time rates method of pay for SP and $\mathrm{BF}$, , on profits. In contrast to the previous estimation, now we include all of the four SP plants, some of which did not change their compensation methods. During the period of our study, the Boston plant shifted from piece rates to gain sharing, the Florida plant shifted from time rates to gain sharing, the Ohio plant remained on time rates, and the UK plant remained on piece rates. This specification allows us to use the plants as controls for each other. ${ }^{14}$ We used two estimation methods to test the effects of time rates and gain sharing: one is the same as the specification in Table 2 and Table 6, Panel $\mathrm{A}^{15}$; the other is to include the lagged value of profits

\footnotetext{
${ }^{14}$ The four plants had remarkably similar production processes during the period of our study. However, Boston also had a large product design function, which designed products for other plants as well. To control for this difference, we included the percent of non-production employees in the plant.

${ }^{15}$ We did not include the interaction terms between time trend and compensation method, because this represents a different meaning from the interaction terms between time trend and changes, which capture s the changes in the slopes of the estimates.
} 
(i.e. the lagged value of the dependent variable) to capture the time effect. The results of both estimation approaches are similar. In Table 6 panel B we show the results of the latter specification. Having gain-sharing raises profitability by about 39 percent and it is precisely estimated relative to piece rates. Paying by time rates is also associated with higher profitability by a marginally significant 34 percent relative to piece rates.

Although wed do not present the estimates in the Tables,, we also combined these data for SP and $\mathrm{BF}$, and found that moving away from piece rates to a method of compensation where individual based incentive is substantially reduced, along with other changes consistent with "modern manufacturing," substantially enhanced the profitability of the firms in our sample. The change in the method of compensation was associated with an increase in profitability of approximately 16 percent.

\section{Conclusions}

The economics of optimal incentives suggest that methods of pay should be different in different production environments. Following Lazear, we initially develop the case where workers produce one product and an owner monitors and receives profits; in this case the optimal incentive system is piece rates. Under this form of compensation, workers receive pay based on the quantity and quality of the output produced. Assuming an efficient allocation of the wages and profits, workers will receive their marginal product and owners will receive normal profits.

In modern manufacturing, hard-to-observe tasks like teamwork, planning, decision making, and problem solving are required, which result in other types of compensation systems being potentially optimal. For example, time rates and gain sharing, where no or only a small amount of pay is variable, may result in optimal output and satisfaction for the workforce. We provide evidence from six establishments within two firms who changed from a piece rate 
method of pay to either time rates or gain sharing. Both our theoretical and empirical analyses suggest that moving away from piece-rate methods of pay for performance may enhance profits in both of the cases we examined. Further, changes for production workers away from piece rates enhance the new workers' attitudes toward teamwork and collaboration. These results suggest one reason why firms may have chosen over the past 50 years to largely abandon piece rate methods of pay in favor of time rates or gain sharing. Our analysis thus shows the importance of distinguishing types of incentive pay: we find that firm profitability under modern manufacturing is consistent with either group incentive pay (such as gain-sharing), or no incentives (such as hourly pay), but inconsistent with individual incentive pay (piece rates). 


\section{References}

Best, Michael H. 1990. New Competition: Institutions of Industrial Restructuring, Cambridge. Ma,. Harvard University Press.

Brown, Charles. "Firms’ Choice of Method of Pay.”1990. Industrial and Labor Relations Review, Vol. 43, Special Issue (February), pp.165-82,

Brown, Martin, \& Peter Philips. 1986. The Decline of the Piece-Rate System in California Canning: Technological Innovation, Labor Management, and Union Pressure, 1890-1947. Business History Review 60(4), 564-601.

Bureau of Labor Statistics. 1997. Industry Wage Survey. U.S. Department of Labor, GPO.

Franceschelli, I., S. Galiani, and E. Gulmez. 2010. "Performance pay and productivity of lowand high-ability workers.” Labour Economics 17(2): 317-322.

Freeman, Richard B., \& Morris M. Kleiner. 2005. The Last American Shoe Manufacturers: Decreasing Productivity and Increasing Profits in the Shift from Piece Rates to Continuous Flow Production. Industrial Relations, 44(2), 307-330.

Gibbs, Michael, 1998. “Lincoln Electric.” Personnel Economics for Managers: Instructors Manual, pp. 4-5, New York: John Wiley and Sons.

Griffith, Rachel, \& Andy Neely. 2006. Incentives and Managerial Experience in Multi-Task Teams: Evidence from Within a Firm. Working paper, Institute for Fiscal Studies, London.

Halley, M. Ryan, 2003 “The Response of Worker Effort to Piece Rates :Evidence from the Midwest Logging Industry”. Journal of Human Resources 38I(4):881-890

Helper, Susan. 2000. Economists and Field Research: "You Can Observe a Lot Just by Watching." American Economic Review, 90(2), 228-232.

Helper, Susan, \& Morris M. Kleiner. 2009. International Differences in Lean Production, Productivity, and Employee Attitudes. In R. B. Freeman and K. Shaw (eds.), International Differences in Business Practices and Productivity. Chicago: University of Chicago Press.

Holmstrom, Bengt, \& Paul Milgrom. 1991. Multitask Principal-Agent Analyses: Incentive Contracts, Asset Ownership, and Job Design. Journal of Law, Economics and Organization, 7(0), 24-52, Special I.

Jacobsen, Joyce P., \& Gilbert L. Skillman. 2004. Labor Markets and Employment Relationships: A Comprehensive Approach. London: Blackwell Publishers. 
Judge, Timothy A., Carl J. Thoresen, Joyce E. Bono, \& Gregory K. Patton. 2001. The Job Satisfaction-Job Performance Relationship: A Qualitative and Quantitative Review.

Psychological Bulletin, 127(3), 376-407.

Lazear, Edward. 2000. Performance Pay and Productivity. American Economic Review, 90(5), 1346-1361.

Lazear, Edward and Kathryn Shaw, 2007. "Personnel Economics: The Economist's View of Human Resources,” Journal of Economic Perspectives, 21, no. 4:91-114.

Lazonick, W. 1991. Business Organization and the Myth of the Market Economy. Cambridge: Cambridge University Press.

, 1993. "Industry Clusters and Global Webs: Organizational Capabilities in the U.S. Economy,” Industrial and Corporate Change, 2 1-24;

Marginson, Paul 2010. "The Decline of Incentive Pay in British Manufacturing" Industrial Relations Journal, Vol. 41, Issue 4, pp. 289-311, July.

Milgrom, Paul, \& John Roberts. 1995. “Complementarities and Fit Strategy, Structure, and Organizational Change in Manufacturing”. Journal of Accounting and Economics, 19(2-3), 179208.

Osterman, P. 2000. "Work reorganization in an era of restructuring: Trends in diffusion and effects on employee welfare.” Industrial and Labor Relations Review 53(2): 179-196.

Paarsch, Harry J. and Bruce Shearer, 2000 'Piece Rates, Fixed Wages and Incentive Effects: Statistical Evidence from Payroll Records." International Economic Review, 41(1): 59-92.

Roy, Donald. 1952. “Quota Restriction and Goldbricking in a Machine Shop” American Journal of Sociology, pp. 427- 442.

Schildkraut, Jeffrey L. 2003. NCS Reviews the Effectiveness of Variable Pay Collection. U.S. Bureau of Labor Statistics.Available at http://www.bls.gov/opub/cwc/cm20030324ar01p1.htm.

Seiler, Eric.“Piece Rate v. Time Rate: The Effect of Incentives on Earnings.” 1984. Review of Economics and Statistics, Vol. 66, no. 3 (August), pp. 363-76,

Shaw, Jason, Nina Gupta, \& John Delery. 2001. Congruence Between Technology and Compensation Systems: Implications for Strategy Implementation. Strategic Management Journal, 22(4), 379-386.

Shaw, K. 2009. “Insider econometrics: A roadmap with stops along the way.” Labour Economics 16(6): 607-617. 
Snell, Scott, \& James Dean. 1994. Strategic Compensation for Integrated Manufacturing: The Moderating Effects of Jobs and Organizational Inertia. Academy of Management Journal, 37, 1109-1140.

Thiele, V. 2010. “Task-specific abilities in multi-task principal-agent relationships.” Labour Economics. 17, 4 (August), pp. 690-698. 
Figure 1. Impacts of modern manufacturing on optimal compensation

\begin{tabular}{|c|c|c|}
\hline$\frac{\text { Feature of modern }}{\text { manufacturing } \rightarrow}$ & impact on production function $\rightarrow$ & desirability of piece rates \\
\hline $\begin{array}{l}\text { Increased emphasis } \\
\text { on: }\end{array}$ & Increased return to: & Reduced due to: \\
\hline Quality & $\begin{array}{l}\text { effort on hard-to-observe tasks, } \\
\text { such as suggestions for process } \\
\text { improvement } \\
\text { multi-tasking } \\
\text { (workers use observation gained } \\
\text { while producing to improve } \\
\text { process) }\end{array}$ & $\begin{array}{l}\text { low motivation to develop, } \\
\text { share ideas that cross job } \\
\text { boundaries, require } \\
\text { teamwork }\end{array}$ \\
\hline Product Variety & $\begin{array}{l}\text { effort on hard-to-observe tasks } \\
\text { such as de-bugging process for } \\
\text { new products } \\
\text { multi-tasking (complex scheduling } \\
\text { increases return to workers who } \\
\text { can produce multiple products, do } \\
\text { both set-ups and production) }\end{array}$ & $\begin{array}{l}\text { fights, risk in establishing } \\
\text { rates on new products } \\
\text { difficulty of establishing } \\
\text { rate that gives workers an } \\
\text { incentive to switch to the } \\
\text { task that is most highly } \\
\text { valued at that moment }\end{array}$ \\
\hline JIT production & $\begin{array}{l}\text { producing exact quantity } \\
\text { demanded } \\
\text { multi-tasking due to increased } \\
\text { return to speedy problem-solving; } \\
\text { Lack of space on line; lack of time } \\
\text { for specialized workers to learn } \\
\text { about problems }\end{array}$ & $\begin{array}{l}\text { low return to extra } \\
\text { production incentivized by } \\
\text { piece rate } \\
\text { low effort on hard to } \\
\text { observe tasks that increase } \\
\text { quality } \\
\text { difficulty in valuing } \\
\text { individual contribution to } \\
\text { process improvements, } \\
\text { training at any point in time }\end{array}$ \\
\hline
\end{tabular}


Figure 2: The timing of the movement away from piece rates in the manufacturing establishments

\section{Panel A Big Foot}

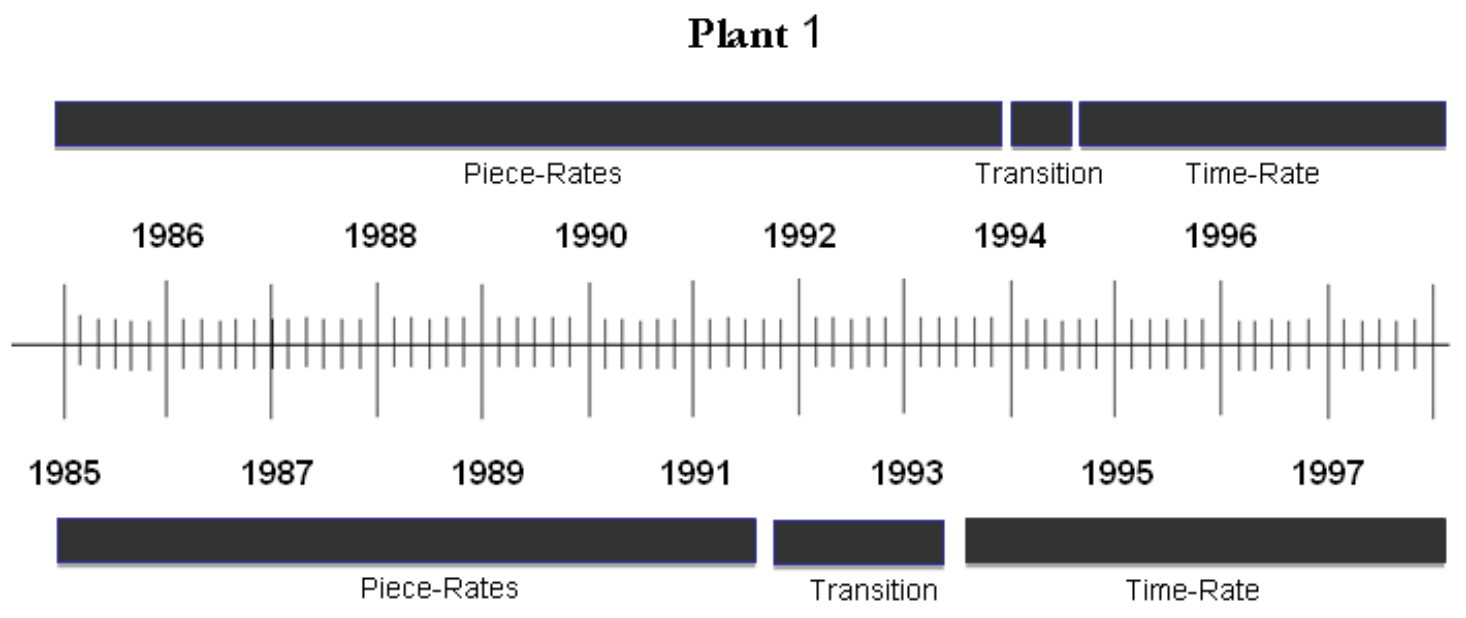

Plant 2

Panel B Small Parts

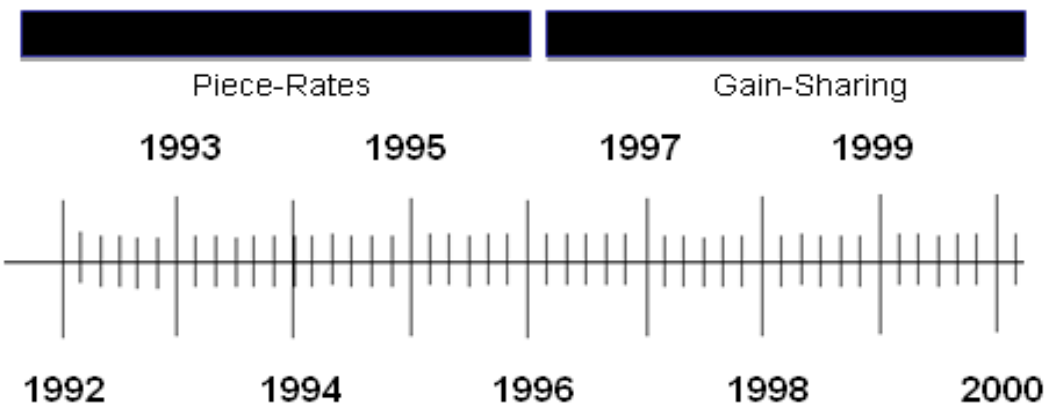


Figure 3: Profits over time

\section{Panel A Big Foot}

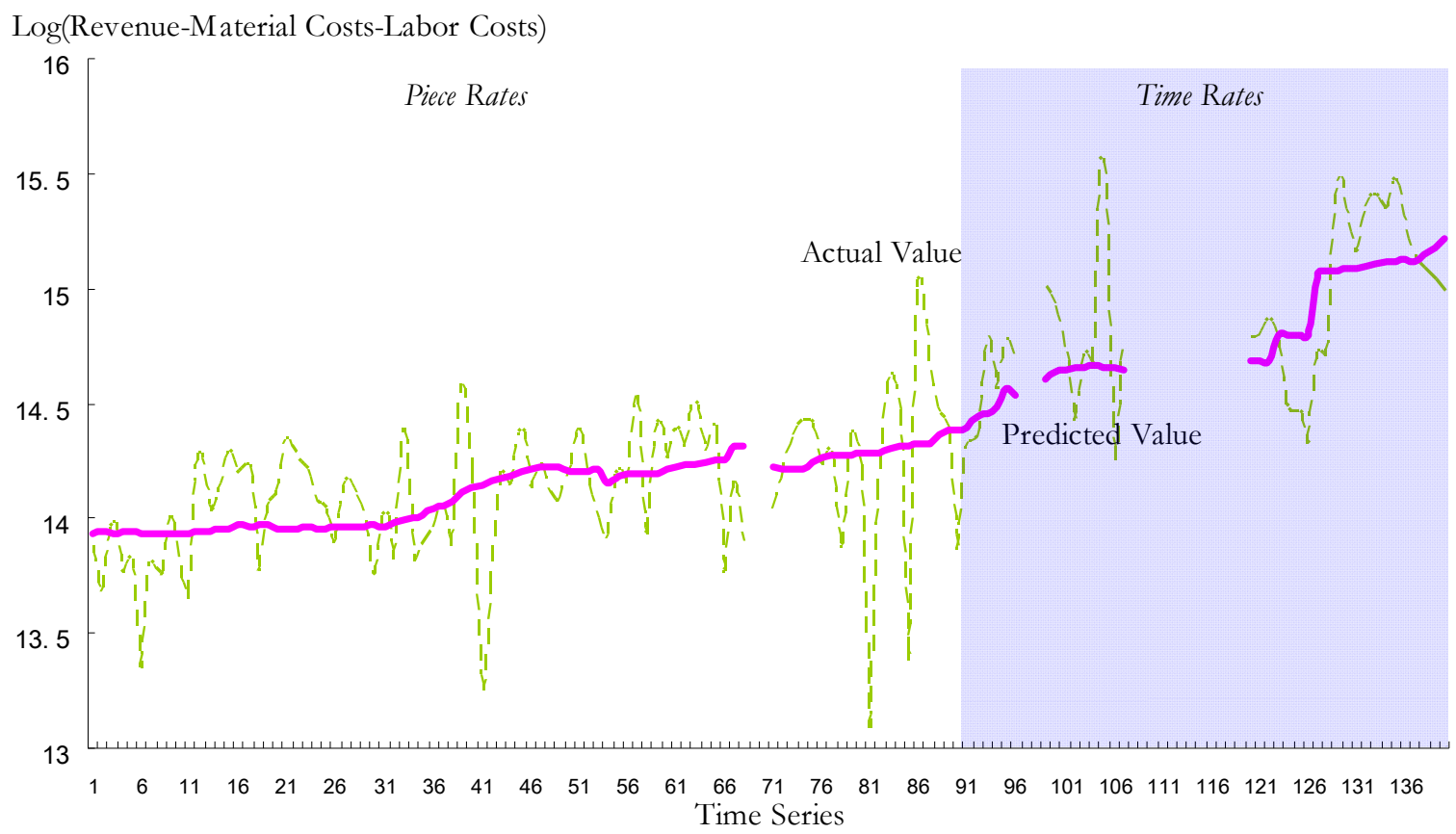

\section{Panel B Small Parts}

$\log ($ Revenue-Material Costs-Labor Costs)

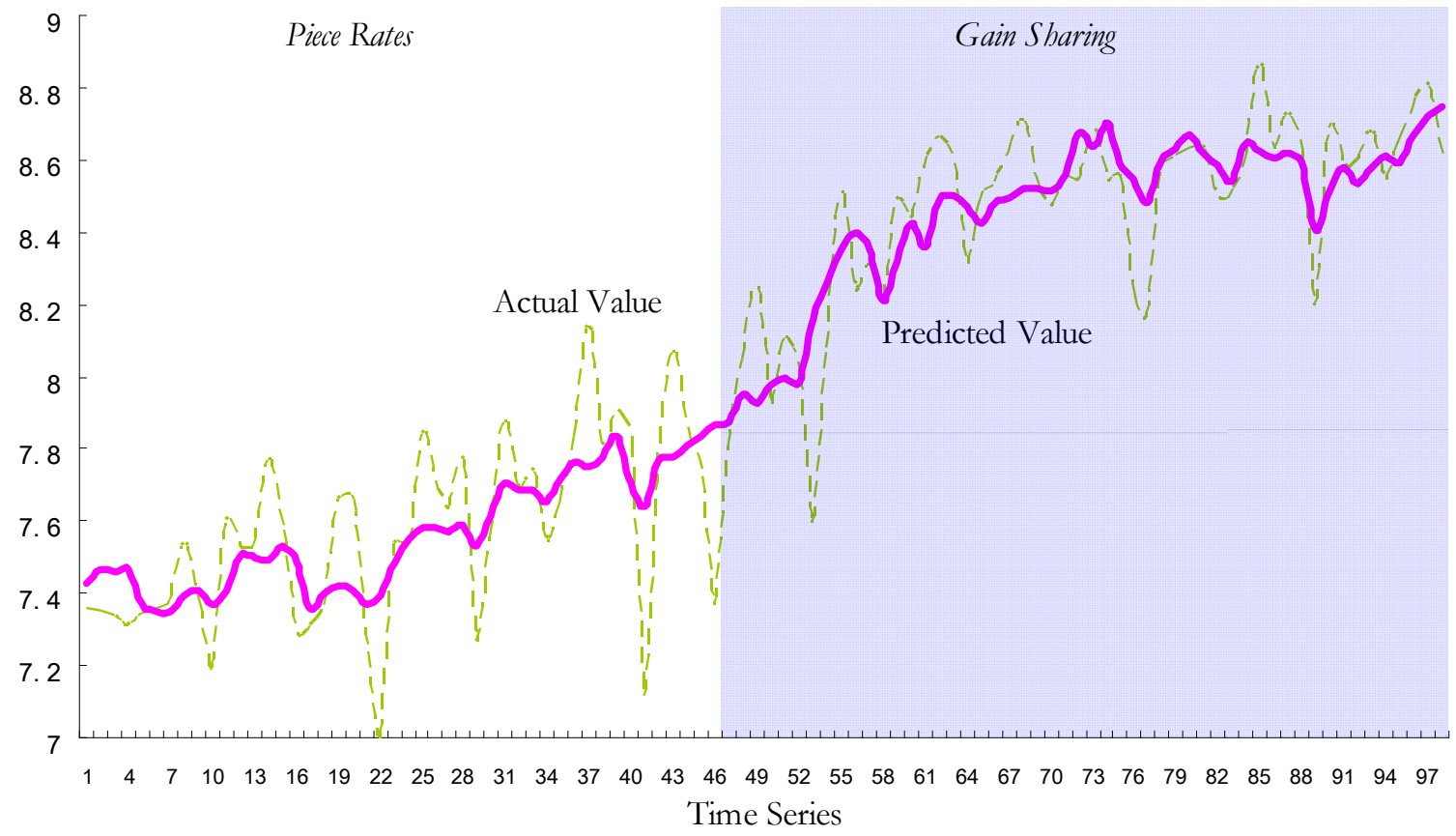

Note: The estimation specification of the predicted value is log_grossprofit $=\mathrm{f}\left(\log \_\right.$assets, time, vag, vag*time, log_headcount, fixed effects) 
Table 1 Descriptive Statistics and Explanation of Variables

\begin{tabular}{|c|c|c|c|c|}
\hline & & & & \\
\hline & Mean & SD & Mean & SD \\
\hline Headcount & 364.98 & 93.13 & 702.95 & 243.76 \\
\hline $\begin{array}{l}\text { Asset per } \\
\text { production } \\
\text { worker }\end{array}$ & N/A & N/A & $\$ 106898.1$ & 8554.96 \\
\hline $\begin{array}{l}\text { Labor cost } \\
\text { per } \\
\text { production } \\
\text { worker }\end{array}$ & $\$ 2075.44$ & 539.10 & $\$ 649.7428$ & 103.38 \\
\hline $\begin{array}{l}\text { Material cost } \\
\text { per } \\
\text { production } \\
\text { worker }\end{array}$ & $\$ 5221.37$ & 1449.33 & $\$ 6131.57$ & 2408.71 \\
\hline $\begin{array}{l}\text { Net sales per } \\
\text { production } \\
\text { worker }\end{array}$ & $\$ 13524.3$ & 3412.752 & $\$ 14042.16$ & 3730.19 \\
\hline $\begin{array}{l}\text { Production } \\
\text { volumes }\end{array}$ & $\$ 255,994.7$ & 101286.3 & $\$ 10,896,330$ & 5965891 \\
\hline $\begin{array}{l}\text { Pairs of } \\
\text { shoes } \\
\text { produced }\end{array}$ & 4052.875 & 1095.514 & N/A & N/A \\
\hline $\begin{array}{l}\text { Planned } \\
\text { pairs of } \\
\text { shoes }\end{array}$ & 4107.038 & 1076.775 & N/A & N/A \\
\hline $\begin{array}{l}\text { Value added } \\
\text { profit }\end{array}$ & $\$ 2,324,016$ & 1058492 & $\$ 5,878,878$ & 2478649 \\
\hline $\begin{array}{l}\text { Number of } \\
\text { Observations }\end{array}$ & & & & \\
\hline
\end{tabular}

Notes: net sales, labor cost, material cost and total asset are in dollars; Monthly data;

Change Coded as zero when the data points' periods are under piece rates; coded as 1 when the data points' periods are under gain sharing or time rates.

Headcount Number of manufacturing workers

Asset $\quad$ Asset of Small Part

Labor Cost Compensation costs

Material Variable production costs

Costs

Transition It is a period at Big Foot prior to the complete transformation. In the period, part of the Effects plants changed to time rates, while other part of the plants remains in piece rates.

Full Effort It is period at Big Foot during the transition where workers maximized their effort Effects hoping for a higher time rate during their entire employment at BF.

Time Time trend: $1,2,3, \ldots, n$ for monthly data. For Small Parts, $n=98$, and Time $=47$ is the implementation of gain sharing. For Big Foot, $n=140$, and Time $=102$ is the full implementation of time rates for Plant 1 , Time $=90$ is the full implementation of time rates for Plant 2. 
Sales $\quad$ Income from sales

Production Production volumes in thousands of dollars for Small Parts

Pairs $\quad$ For BF, pairs of shoes produced

Gap The difference between the planned pairs of shoes to be produced and the actual pairs of shoes produced

Self-ranking From the employee survey of Small Parts: "I meet production targets."

in terms of

meeting

production

targets

Frequency

of

From the employee survey of Small Parts: "I talk with my co-workers about work

teamwork

Frequency From the employee survey of Small Parts: "I make suggestions to improve the way the of making factory runs.”

suggestions

General

satisfaction

Value- $\quad$ sales-material costs- labor costs

added

profit 
Table 2 Analyzing observable and unobservable tasks in manufacturing

Panel A. Big Foot (BF); change from piece rates to time rates

\begin{tabular}{lcccc}
\hline \multirow{2}{*}{$\begin{array}{c}\text { Dependent } \\
\text { Variable }\end{array}$} & $\begin{array}{c}\text { Ln (pairs } \\
\text { produced) }\end{array}$ & $\begin{array}{c}\text { Ln (pairs } \\
\text { produced*price) }\end{array}$ & $\begin{array}{c}\text { Ln(material cost } \\
\text { per pair of } \\
\text { shoes) }\end{array}$ & $\begin{array}{c}\text { Ln(material } \\
\text { cost/price per } \\
\text { pair of shoes) }\end{array}$ \\
\cline { 2 - 5 } Change & $-.20^{* *}(.02)$ & $-.23^{* *}(.06)$ & $-.19^{* *}(.07)$ & $-.16^{*}(.08)$ \\
Change*time & $.0008(.0007)$ & $.0004(.0016)$ & $-.001(.002)$ & $-.003(.002)$ \\
Time & $.0002(.0002)$ & $.005^{* *}(.001)$ & $.007(.0008)$ & $.002^{*}(.0009)$ \\
Log headcount & $.92^{* *}(.02)$ & $.91^{* *}(.05)$ & $.03(.06)$ & $.04(.07)$ \\
$\begin{array}{l}\text { Transition } \\
\text { effect }\end{array}$ & $-.07^{* *}(.02)$ & $-.07(.05)$ & $-.004(.06)$ & $.02(.07)$ \\
$\begin{array}{l}\text { Full effort } \\
\text { effect }\end{array}$ & $.0003(.02)$ & $.008(.04)$ & $.06(.05)$ & $.02(.06)$ \\
$\begin{array}{l}\text { Constant } \\
\text { Adjusted R- }\end{array}$ & $2.82^{* *}(.12)$ & $9.65^{* *}(.28)$ & $5.49^{* *}(.36)$ & $1.69 * *(.41)$ \\
squared & .94 & .81 & .48 & .06 \\
$\begin{array}{l}\text { Number of } \\
\text { observation }\end{array}$ & 240 & 247 & 240 & 238 \\
\hline
\end{tabular}

Panel B. Small Parts (SP); change from piece rates to gain sharing

\begin{tabular}{lcc}
\hline \multirow{2}{*}{$\begin{array}{c}\text { Dependent } \\
\text { Variable }\end{array}$} & Sales Volume & Hard-to-Observe Tasks \\
\cline { 2 - 3 } & Ln(production) & $\begin{array}{c}\text { Ln(percentage of material cost in } \\
\text { production) }\end{array}$ \\
\hline Change & $-.62^{* *}(.16)$ & $-.14^{*}(.07)$ \\
Change*time & $.01^{* *}(.003)$ & $.003(.002)$ \\
Time & $-.010^{* *}(.003)$ & $-.002(.002)$ \\
Log headcount & $1.46^{* *}(.25)$ & $1.05^{* *}(.12)$ \\
Log asset & $1.42^{* *}(.40)$ & $-.35 \dagger(.20)$ \\
Constant & $-15.34^{* *}(3.69)$ & $-3.68^{*}(1.83)$ \\
$\begin{array}{l}\text { Adjusted R- } \\
\text { squared }\end{array}$ & .96 & .88 \\
$\begin{array}{l}\text { Number of } \\
\text { observation }\end{array}$ & 98 & 98 \\
\hline
\end{tabular}

Empirical Test of Proposition 4 and Proposition 2-3

Source: Based on company's data. Standard errors are in parentheses.

Notes: Time is a monthly time trend. The results are similar with or without polynomial time trend. Big Foot regressions include a plant dummy. $\dagger \mathrm{p}<.10,{ }^{*} \mathrm{p}<.05,{ }^{* *} \mathrm{p}<.01$ 
Table 3

Big Foot: Effect of compensation system changes on the gap between planned output and actual output

\begin{tabular}{cc}
\hline Change & $-.03^{* *}(.01)$ \\
Total headcount & $.0001^{*}(.00005)$ \\
Transition effect & $-.03^{* *}(.01)$ \\
Full Effort effect & $.06^{* *}(.01)$ \\
Constant & $-.04^{*}(.02)$ \\
Adjusted R-squared & 0.13 \\
$\mathrm{~N}$ & 240 \\
\hline
\end{tabular}

Empirical Test of Proposition 1

Source: Based on company's data. Standard errors are in parentheses.

Notes: Regression includes a plant dummy to account for fixed effects.

$\dagger \mathrm{p}<.10,{ }^{*} \mathrm{p}<.05, * * \mathrm{p}<.01$ 
Table 4

Small Parts: Comparing employee perceptions on work for those hired before and after gain sharing Small

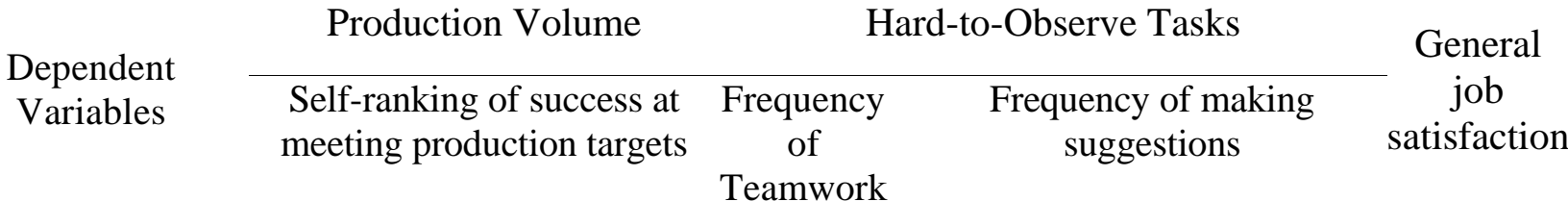

\begin{tabular}{lcccc} 
Hired after gain- & -.11 & $.28+$ & .26 & .18 \\
sharingsharingsharing & $(.11)$ & $(.16)$ & $(.16)$ & $(.12)$ \\
Vietnamese & $-.23 \dagger$ & .13 & .13 & $.38^{* *}$ \\
& $(.13)$ & $(.19)$ & $(.19)$ & $(.14)$ \\
Cape Verde & $-.35^{* *}$ & .03 & -.13 & .17 \\
& $(.13)$ & $(.19)$ & $(.19)$ & $(.14)$ \\
Constant & $3.60^{* *}$ & $3.26^{* *}$ & $3.00^{* *}$ & $3.04^{* *}$ \\
& $(.10)$ & $(.15)$ & $(.16)$ & $(.12)$ \\
Adjusted R- & 0.02 & .002 & .005 & .02 \\
$\mathrm{~N}$ & 428 & 439 & 422 & 478 \\
\hline
\end{tabular}

Empirical Test of Proposition 3

Source: Based on survey data. Standard errors are in parentheses.

Notes: $\dagger \mathrm{p}<.10, * \mathrm{p}<.05, * * \mathrm{p}<.01$ 
Table 5

Labor costs and changes in compensation

Regression estimates of the effects of compensation method changes on labor costs

\begin{tabular}{lcc}
\hline $\begin{array}{l}\text { Dependent Variable: } \\
\quad \text { Ln (labor costs per } \\
\quad \text { employee) }\end{array}$ & Big Foot & Small Parts \\
Change & $-.24(.23)$ & $-.71^{*}(.28)$ \\
Change*time & $-.002(.002)$ & $.007(.004)$ \\
Time & $.006^{* *}(.001)$ & $-.007(.004)$ \\
Log asset & $\mathrm{N} / \mathrm{A}$ & $1.49 * *(.40)$ \\
Transition effect & $-.10(.06)$ & $\mathrm{N} / \mathrm{A}$ \\
Full effort effect & $.17 * *(.05)$ & $\mathrm{N} / \mathrm{A}$ \\
Constant & $7.33(.33)$ & $-16.86(4.42)$ \\
R-squared & 0.33 & 0.27 \\
Number of Observation & 247 & 99 \\
Empirical test of Proposition 6 & & \\
Source: Based on company data. Standard errors are in parentheses. \\
Notes: $\dagger$ p $<.10, *$ p<.05, ** $<<.01$ \\
$*$ Big Foot regression includes a plant dummy to separately account for the performance \\
of each of BF's two plants.
\end{tabular}


Table 6

Panel A: Profitability and changes in compensation

Regression estimates of the effects of compensation method changes on profitability

\begin{tabular}{lcc}
\hline \multicolumn{1}{c}{$\begin{array}{c}\text { Dependent Variable: } \\
\quad \text { Ln (gross profit per } \\
\quad \text { employee) }\end{array}$} & Big Foot & Small Parts \\
Change & $.18^{* *}(.07)$ & $.21^{*}(.11)$ \\
Change*time & $.005^{* *}(.002)$ & $-.003^{* *}(.001)$ \\
Time & $-.003^{* *}(.001)$ & $.002^{*}(.001)$ \\
Log headcount & $-.04(.058)$ & $-.76^{* *}(.09)$ \\
Log asset & $\mathrm{N} / \mathrm{A}$ & $.26 \dagger(.15)$ \\
Transition effect & $.03(.06)$ & $\mathrm{N} / \mathrm{A}$ \\
Full effort effect & $-.07(.05)$ & $\mathrm{N} / \mathrm{A}$ \\
Constant & $-.47(.33)$ & $1.24(1.37)$ \\
R-squared & 0.26 & 0.87 \\
Number of Observation & 247 & 98 \\
\hline
\end{tabular}

Panel B: Effects of time rates and gain sharing

Regression estimates of the effects of compensation methods in profitability

\begin{tabular}{lcc}
\hline \multicolumn{1}{c}{$\begin{array}{c}\text { Dependent Variable: } \\
\text { Ln (gross profit per } \\
\quad \text { employee) }\end{array}$} & Big Foot & Small Parts \\
Gain Sharing & $\mathrm{N} / \mathrm{A}$ & $.39^{* *}(.06)$ \\
Time Rates & $.18^{* *}(.05)$ & $.34^{* *}(.14)$ \\
Log asset per employee & $\mathrm{N} / \mathrm{A}$ & $-.02(.04)$ \\
DV of the previous & $.11 \dagger(.06)$ & $.22^{* *}(.06)$ \\
month & & \\
Percentage of non- & $\mathrm{N} / \mathrm{A}$ & $.06^{* *}(.01)$ \\
production employees & $.03(.07)$ & $\mathrm{N} / \mathrm{A}$ \\
Transition effect & $-.04(.07)$ & $\mathrm{N} / \mathrm{A}$ \\
Full effort effect & $7.57^{* *}(.55)$ & $-.62^{*}(.27)$ \\
Constant & 0.24 & 0.85 \\
R-squared & 245 & 263 \\
Number of Observation & &
\end{tabular}

Empirical test of Proposition 7

Source: Based on company data. Standard errors are in parentheses.

Notes: Gross profit is equal to the income that the companies have after subtracting material cost and labor cost.. $\dagger \mathrm{p}<.10, * \mathrm{p}<.05,{ }^{* *} \mathrm{p}<.01$

* Big Foot regression includes a plant dummy to separately account for the performance of each of BF's two plants.

* Small Parts regression in Panel B includes dummies to account for the fixed effects of different plants located in Boston, Ohio, Florida, and U.K. 
Appendix A: Trends in job satisfaction at Big Foot

Employee Satisfaction Before, During and After the Transition from Piece Rates to Time Rates

\begin{tabular}{|c|c|c|c|c|c|c|c|c|c|c|}
\hline \multirow[b]{2}{*}{ Yes\% } & \multicolumn{3}{|c|}{$\begin{array}{c}1992 \\
\text { Before the Change }\end{array}$} & \multicolumn{3}{|c|}{$\begin{array}{c}1993 \\
\text { During the Change }\end{array}$} & \multicolumn{3}{|c|}{$\begin{array}{l}1995 \\
\text { After the Change }\end{array}$} & \multirow{2}{*}{$\begin{array}{c}1997 \\
\text { After } \\
\text { the } \\
\text { Change }\end{array}$} \\
\hline & $\begin{array}{l}\text { (1) } \\
\text { Good } \\
\text { cooperation } \\
\text { between } \\
\text { departments }\end{array}$ & $\begin{array}{l}(2) \\
\text { Too many } \\
\text { problems } \\
\text { between } \\
\text { coworkers }\end{array}$ & $\begin{array}{l}(3) \\
\text { The } \\
\text { longer I } \\
\text { work } \\
\text { here the } \\
\text { more I } \\
\text { enjoy it }\end{array}$ & $\begin{array}{l}\text { (1) } \\
\text { Good } \\
\text { cooperation } \\
\text { between } \\
\text { departments }\end{array}$ & $\begin{array}{l}(2) \\
\text { Too many } \\
\text { problems } \\
\text { between } \\
\text { coworkers }\end{array}$ & $\begin{array}{l}\text { (3) } \\
\text { The } \\
\text { longer I } \\
\text { work } \\
\text { here the } \\
\text { more I } \\
\text { enjoy it }\end{array}$ & $\begin{array}{l}\text { (1) } \\
\text { Good } \\
\text { cooperation } \\
\text { between } \\
\text { coworkers }\end{array}$ & $\begin{array}{l}(2) \\
\text { Too many } \\
\text { problems } \\
\text { between } \\
\text { coworkers }\end{array}$ & $\begin{array}{l}\text { (3) } \\
\text { The } \\
\text { longer I } \\
\text { work } \\
\text { here the } \\
\text { more I } \\
\text { enjoy it }\end{array}$ & \\
\hline $\begin{array}{l}\text { Yes\% } \\
\text { No\% }\end{array}$ & $\begin{array}{l}53 \\
47\end{array}$ & $\begin{array}{l}30 \\
70\end{array}$ & $\begin{array}{l}69 \\
31\end{array}$ & $\begin{array}{l}27 \\
73\end{array}$ & $\begin{array}{l}70 \\
30\end{array}$ & $\begin{array}{l}30 \\
70\end{array}$ & $\begin{array}{l}42 \\
58\end{array}$ & $\begin{array}{l}50 \\
48\end{array}$ & $\begin{array}{l}49 \\
51\end{array}$ & \\
\hline $\begin{array}{c}\text { Satisfied or } \\
\text { very } \\
\text { Satisfied } \\
\text { (\%) } \\
\text { Dissatisfied } \\
\text { (\%) } \\
\text { Neither } \\
(\%)\end{array}$ & & & & & & & & & & $\begin{array}{l}51 \\
\\
18 \\
32\end{array}$ \\
\hline
\end{tabular}


Appendix B: Descriptive statistics of before and after changes in compensation methods Big Foot

\section{Small Parts}

Before

After

Before

After

\begin{tabular}{|c|c|c|c|c|c|c|c|c|}
\hline & Mean & $\mathrm{SD}$ & Mean & SD & Mean & SD & Mean & SD \\
\hline Headcount & 346.53 & 71.47 & $415.32 * *$ & 127.66 & 488.31 & 70.23 & $946.48 * *$ & 93.70 \\
\hline $\begin{array}{l}\text { Asset per } \\
\text { production } \\
\text { worker }\end{array}$ & N/A & N/A & N/A & N/A & $\$ 106977.1$ & 5310.07 & $\$ 106808.4$ & 11214.84 \\
\hline $\begin{array}{l}\text { Labor Cost } \\
\text { per } \\
\text { production } \\
\text { worker }\end{array}$ & $\$ 2115.10$ & 573.73 & $\$ 1960.12 *$ & 404.78 & $\$ 624.32$ & 99.16 & $\$ 672.72 * *$ & 102.64 \\
\hline $\begin{array}{l}\text { Material } \\
\text { Cost per } \\
\text { production } \\
\text { worker }\end{array}$ & $\$ 5143.31$ & 1449.23 & $\$ 5448.37 \dagger$ & 1436.67 & $\$ 4067.79$ & 825.83 & $\$ 7957.23^{* *}$ & 1786.94 \\
\hline $\begin{array}{l}\text { Net Sales } \\
\text { per } \\
\text { production } \\
\text { worker }\end{array}$ & $\$ 13235.48$ & 3102.74 & \$14354.63* & 4093.29 & $\$ 11,086.78$ & 2074.03 & $\$ 17054.38^{* *}$ & 2379.13 \\
\hline $\begin{array}{l}\text { Production } \\
\text { volume }\end{array}$ & $\$ 239,494.3$ & 91871.22 & $\$ 307,202.9 * *$ & 112347 & $\$ 5,606,849$ & 1653921 & $\$ 16,287,540^{* *}$ & 3328595 \\
\hline $\begin{array}{l}\text { Pairs of } \\
\text { shoes } \\
\text { produced }\end{array}$ & 4090.297 & 1095.125 & 3935.448 & 1097.912 & N/A & N/A & N/A & N/A \\
\hline $\begin{array}{l}\text { Planned } \\
\text { pairs of } \\
\text { shoes }\end{array}$ & 4110.396 & 1063.508 & 4096.5 & 1126.854 & N/A & N/A & N/A & N/A \\
\hline Profit & $\$ 2,143,315$ & 962667.6 & $\$ 2,851,777$ & 1153345 & $\$ 3,499,478$ & 792340.7 & $\$ 7,983,731^{* *}$ & 1227749 \\
\hline $\begin{array}{l}\text { Number of } \\
\text { Observations }\end{array}$ & \multicolumn{2}{|c|}{169} & \multicolumn{2}{|l|}{96} & \multicolumn{2}{|c|}{75} & \multicolumn{2}{|l|}{52} \\
\hline
\end{tabular}

Notes: net sales, labor cost, material cost and total asset are in dollars; Monthly data; $\dagger \mathrm{p}<.10,{ }^{*} \mathrm{p}<.05,{ }^{* *} \mathrm{p}<.01$, two-tailed. 
Appendix C:

Proof of Proposition 1:

Since we are not dealing with the hard-to-observe tasks here, we will simplify the firms’ problem to $\Pi=B(q)-L$ for convenience.

\section{Time Rates and Gain Sharing}

The firm asks the agent to produce the optimal volume $\hat{q}$. If output consistently falls short of the principal's expectation, the principal will hire extra workers or replace the low-performance worker with a new worker to make sure the workforce will always produce the desired output. Thus we have $|\dot{q}-\hat{q}|=0$.

Piece Rates. In contrast to time rates or gain sharing, the principal does not directly tell the agent how many to produce, but instead announces a piece rate, $\alpha$, to the agent who chooses $q$ to maximize his utility, $\alpha^{*} q-D(q, \theta)$. The term $D(q, \theta)$ is the monetary value of the agent's disutility of producing $q$ pieces, with $D_{1}(q, \theta)>0$ and $D_{11}(q, \theta)>0$. The variable $\theta$ is a random variable representing the uncertainty of the disutility function with the expectation of its distribution being zero. The variable $\theta$ comes from the information asymmetry between the principal and agent and frequent changes of product design. The more frequently the product designs change, the more uncertain the principal is about how much effort the agent needs to make to produce the commodity. Thus, the standard deviation of the distribution of $\theta$ is large.

The agent's maximization yields the first-order condition $\alpha=D_{1}(\tilde{q}, \theta)$ from which we deduce a reaction function $h(\alpha, \theta)$. This satisfies $\alpha=D_{1}(h(\tilde{\alpha}, \theta), \theta)$.

The optimal piece rate announcement to the agent is obtained from maximizing 
$\operatorname{Max}_{\alpha} E[B(h(\alpha, \theta))-\alpha * h(\alpha, \theta)]$

i.e.

$E\left[B_{1}(h(\tilde{\alpha}, \theta)) h_{1}(\tilde{\alpha}, \theta)\right]=E\left[-h(\tilde{\alpha}, \theta)-\tilde{\alpha} h_{1}(\tilde{\alpha}, \theta)\right]$

We obtain: $\tilde{\alpha}=\frac{E\left[B_{1}(h(\tilde{\alpha}, \theta)) h_{1}(\tilde{\alpha}, \theta)-h(\tilde{\alpha}, \theta)\right]}{E\left[h_{1}(\tilde{\alpha}, \theta)\right]}$, and the agent will respond with $\tilde{q}=h(\tilde{\alpha}, \theta)$, which is transmitted to the principal. Notice that $\tilde{q}$ is a function of the random variable $\theta$ both directly and indirectly via $\tilde{\alpha}$. Thus, $\tilde{q}$ deviates from its optimal value $E(\tilde{q})$, i.e., $|\tilde{q}-E(\tilde{q})|=|\tilde{q}-\hat{q}|=|f(\theta)|>0$.

Transition from piece-rates to time-rates and gain-sharing: Switching from piecerates makes the firms better able to produce the exact optimal volume, because $|\dot{q}-\hat{q}|=0<|\tilde{q}-\hat{q}|$

\section{Proof of Proposition 2}

To investigate how piece-rates affect the agent's effort, we set the agent's utility function as $U=p\left(t_{e}\right)\left(\beta+\alpha t_{q}+\frac{\lambda B(e, q)}{N}\right)-D\left(t_{e}, t_{q}\right)$. To maximize the utility function, the agent chooses $t_{e}{ }^{*}$ and $t_{q} *$ to satisfy the first order condition:

$$
\frac{\partial U}{\partial t_{e}}=f^{1}=p^{\prime}\left(t_{e}^{*}\right)\left(\beta+\alpha t_{q}^{*}+\frac{\lambda B(e, q)}{N}\right)+p\left(t_{e}^{*}\right)\left(\alpha \frac{\partial t_{q}}{\partial t_{e}}+\frac{\lambda}{N}\left(B_{1}+B_{2} \frac{\partial t_{q}}{\partial t_{e}}\right)\right)-D_{1}-D_{2} \frac{\partial t_{q}}{\partial t_{e}}=0
$$

The above equations imply that under piece rates, the workers' effort must satisfy:

$D_{1}^{p}=p^{\prime}\left(t_{e}^{*}\right)\left(\beta+\alpha t_{q}^{*}\right)+p\left(t_{e}^{*}\right) \alpha \frac{\partial t_{q}}{\partial t_{e}}-D_{2} \frac{\partial t_{q}}{\partial t_{e}}$. But if a firm uses time rates, the workers' 
effort becomes $D_{1}{ }^{t}=p^{\prime}\left(t_{e}{ }^{*}\right) \beta-D_{2} \frac{\partial t_{q}}{\partial t_{e}}$. If a firm uses gain-sharing, the workers' effort becomes $D_{1}^{g}=p^{\prime}\left(t_{e}^{*}\right)\left(\beta+\frac{\lambda B(e, q)}{N}\right)+p\left(t_{e}^{*}\right) \frac{\lambda}{N}\left(B_{1}+B_{2} \frac{\partial t_{q}}{\partial t_{e}}\right)-D_{2} \frac{\partial t_{q}}{\partial t_{e}}$.

\section{Switching from piece-rates to time-rates}

By contrasting the disutility functions, we can contrast the effort allocation under the compensation schemes:

$$
D_{1}^{t}-D_{1}^{p}=-p^{\prime}\left(t_{e}^{*}\right) \alpha t_{q}^{*}-p\left(t_{e}^{*}\right) \alpha \frac{\partial t_{q}}{\partial t_{e}}+\left(D_{2}^{p}-D_{2}{ }^{t}\right) \frac{\partial t_{q}}{\partial t_{e}}
$$

The firm will set the piece rate as $\hat{\alpha}=D_{2}\left(\hat{t}_{e}, \hat{t}_{q}\right)$, so that the workers will devote the desired amount of effort $\hat{t}_{q}$ and produce the exact quantity of $\hat{q}$. Under time-rates and gain-sharing, the firms simply require the workers to produce $\hat{q}$. Since it is an observable task, the workers will risk being laid off if they consistently do not reach the target $\hat{q}$.

Thus, $D_{2}^{p}-D_{2}{ }^{t}=D_{2}{ }^{p}-D_{2}{ }^{g}=0$

The above equation indicates that workers' effort on hard-to-observe tasks are determined by the piece rate $(\alpha)$, the extent to which a worker's effort can be observed $\left(p^{\prime}\left(t_{e}^{*}\right)\right.$ and $\left.p\left(t_{e}^{*}\right)\right)$, and the trade-off between the effort dedicated to the two tasks $\left(\frac{\partial t_{q}}{\partial t_{e}}\right)$ which is negative. When the effort on hard-to-observe tasks is very hard to observe, (i.e. $p^{\prime}\left(t_{e}\right) \rightarrow 0, p\left(t_{e}\right) \rightarrow 1$ ) and $\alpha$ is large, $D_{1}{ }^{t}-D_{1}{ }^{p}>0$ becomes positive, which indicate that the effort on observable tasks decreases and the effort on hard-to-observe tasks increases. 
Switching from piece-rates to gain-sharing

$$
D_{1}^{g}-D_{1}^{p}=p^{\prime}\left(t_{e}{ }^{*}\right) \frac{\lambda B(e, q)}{N}+p\left(t_{e}{ }^{*}\right) \frac{\lambda}{N}\left(B_{1}+B_{2} \frac{\partial t_{q}}{\partial t_{e}}\right)-p^{\prime}\left(t_{e}{ }^{*}\right) \alpha t_{q}{ }^{*}-p\left(t_{e}{ }^{*}\right) \alpha \frac{\partial t_{q}}{\partial t_{e}}+\left(D_{2}{ }^{p}-D_{2}{ }^{g}\right) \frac{\partial t_{q}}{\partial t_{e}}
$$

Similar to the situation of switching to time-rates, when tasks become hard to observe, (i.e. $p^{\prime}\left(t_{e}\right) \rightarrow 0$ and $p\left(t_{e}\right) \rightarrow 1$ ), $D_{1}^{g}-D_{1}{ }^{p}>0$ is positive, which indicates that the effort devoted to hard-to-observe tasks increases when a firm switches from piece rates to time rates.

\section{Proof of Proposition 3}

For simplicity, we assume hard-to-observe tasks are completely unobservable (i.e. $p\left(t_{e}\right)=1$ ) hereafter, unless otherwise mentioned.

Piece Rates. An agent's utility under piece rates is $U_{p}=\beta+\alpha_{q} q-D\left(t_{e}, t_{q}\right)$.

Thus, we have $\frac{d U^{*}{ }_{p}}{d A_{q}}=\frac{\partial U^{*}{ }_{p}}{\partial q} \frac{\partial q}{\partial A_{q}}+\frac{\partial U^{*}{ }_{p}}{\partial t^{*}{ }_{q}} \frac{\partial t^{*}{ }_{q}}{\partial A_{q}}=\alpha_{q} \frac{\partial q}{\partial A_{q}}-\frac{\partial D^{*}{ }_{p}}{\partial t^{*}{ }_{q}} \frac{\partial t^{*}{ }_{q}}{\partial A_{q}}$, which is greater than zero, because $\frac{\partial t^{*} q}{\partial A_{q}}<0$. The equation shows that two components contribute to the benefit of being fast in producing commodities under piece-rates: higher incomes and lower disutility.

But for the unobservable tasks, we have $\frac{d U^{*} p}{d A_{e}}=0$. 
Gain Sharing. An agent's utility under gain sharing is $U_{g}=\beta+\lambda \frac{B(e, q)}{N}-D\left(t_{e}, t_{q}\right)$. The variables $e$ and $q$ are functions of the agent's ability (denoted as $A_{e}$ and $A_{q}$ ) and effort (denoted as $t_{e}$ and $\left.t_{q}\right) . e=e\left(t_{e}, A_{e}\right) q=q\left(t_{q}, A_{q}\right)$.

As before, since $q$ 's outcome can be easily measured, the principal imposes a rule of $q \geq \hat{q}$ to agents. ${ }^{16}$ To minimize the pain associated with effort, an agent will produce a volume of commodities such that $q^{*}=\hat{q}$, with $t_{q}^{*}$ being the optimal level of effort devoted to the simple tasks. Given the implicit functions, it is clear that $\frac{\partial t_{q}^{*}}{\partial A_{q}}=-\frac{\partial \hat{q} / A_{q}}{\partial \hat{q} / t_{q}^{*}}<0$. Since $\frac{\partial U^{*}{ }_{g}}{\partial t^{*}{ }_{q}}<0$ and $\frac{\partial t^{*}{ }_{q}}{\partial A_{q}}<0$ with $U^{*}{ }_{g}$ being the optimal utility level of an agent under gain sharing, we have $\frac{d U_{g}^{*}}{d A_{q}}=\frac{\partial U^{*}{ }_{g}}{\partial t^{*}} \frac{\partial t_{q}^{*}}{\partial A_{q}}=-\frac{\partial D^{*}{ }_{g}}{\partial t^{*}{ }_{q}} \frac{\partial t_{q}^{*}}{\partial A_{q}}>0$. As for the hard-to-observe tasks, $e$ is hard to measure. Since $\frac{\partial U_{g}^{*}}{\partial B^{*}}>0, \frac{\partial B^{*}}{\partial e^{*}}>0$, and $\frac{\partial e^{*}}{\partial A_{e}}>0$, we have $\frac{d U_{g}^{*}}{d A_{e}}=\frac{\partial U_{g}^{*}}{\partial B^{*}} \frac{\partial B^{*}}{\partial e^{*}} \frac{\partial e^{*}}{\partial A_{e}}>0$.

Time Rates. An agent's utility under gain sharing is $U_{t}=\beta-D\left(t_{e}, t_{q}\right)$. Similar to the case of gain sharing, there is a weak sorting effect in terms of simple tasks because to minimize the pain associated with effort devoted to simple tasks, an agent will produce an outcome such that $q^{*}=\hat{q}$, so $q^{*}\left(t_{q}^{*}, A_{q}\right)=\hat{q}$ with $t_{q}^{*}$ being the optimal level of effort devoted to produce the required quantities of commodities. Given this implicit function, it

\footnotetext{
${ }^{16}$ Zero is the minimum performance standard required by the principal for the observable tasks. If the agents cannot meet the standard, they will be dismissed.
} 
is clear that $\frac{\partial t_{q}^{*}}{\partial A_{q}}=-\frac{\partial e_{q}^{*} / A_{q}}{\partial e_{q}^{*} / t_{q}^{*}}<0$. Since $\frac{\partial U^{*}{ }_{t}}{\partial t^{*}{ }_{q}}<0$ and $\frac{\partial t^{*}{ }_{q}}{\partial A_{q}}<0$ with $U^{*}$ being the

optimal utility level of an agent under gain sharing, we have

$\frac{d U^{*}{ }_{t}}{d A_{q}}=\frac{\partial U^{*}{ }_{t}}{\partial t^{*}} \frac{\partial t^{*}{ }_{q}}{\partial A_{q}}=-\frac{\partial D^{*}{ }_{t}}{\partial t^{*}{ }_{q}} \frac{\partial t^{*}{ }_{q}}{\partial A_{q}}>0$.

Because the wage under time rates does not depend on the ability to perform hardto-observe tasks, and the ability to perform hard-to-observe tasks does not influence an agent's utility under time rates, we have: $\frac{d U^{*}}{d A_{e}}=0$

Transition from Piece Rates to Time Rates/Gain Sharing. From these results, we can see that all of the compensation schemes have sorting effects in terms of abilities to produce certain volumes of commodities quickly. But the sorting effect of piece-rates is stronger than that of time-rates or gain-sharing:

$\frac{d U^{*}{ }_{p}}{d A_{q}}=\alpha_{q} \frac{\partial q}{\partial A_{q}}-\frac{\partial D^{*}{ }_{p}}{\partial t^{*}{ }_{q p}} \frac{\partial t^{*}{ }_{q p}}{\partial A_{q}}>\frac{d U^{*}{ }_{g}}{d A_{q}}=\frac{d U^{*} t^{*}}{d A_{q}}=-\frac{\partial D^{*}{ }_{t}}{\partial t^{*}{ }_{q(g / t)}} \frac{\partial t^{*}{ }_{q(g / t)}}{\partial A_{q}}$, because $\alpha_{q} \frac{\partial q}{\partial A_{q}}>0$ and $\frac{\partial D^{*}{ }_{p}}{\partial t^{*}{ }_{q}}>\frac{\partial D^{*}{ }_{g}}{\partial t^{*}{ }_{q}}=\frac{\partial D^{*}{ }_{t}}{\partial t^{*}{ }_{q}}{ }^{17}$. The intuition behind this is that under piece rates, in addition to saving the pain associated with work $\left(-\frac{\partial D^{*}}{\partial t^{*}} \frac{\partial t^{*}{ }_{q}}{\partial A_{q}}\right)$, agents can get returns $\left(\alpha_{q} \frac{\partial q}{\partial A_{q}}\right)$ from being competent to produce more.

\footnotetext{
${ }^{17}$ To prove this inequality: according to Proposition $1 \mathrm{a}, t^{*}{ }_{q p}>t^{*}{ }_{q g}=t^{*}{ }_{q t}$. Since $D^{\prime \prime}>0$, we have $\frac{\partial D_{p}^{*}}{\partial t^{*}{ }_{q p}}>\frac{\partial D^{*}{ }_{g}}{\partial t^{*}{ }_{q g}}=\frac{\partial D^{*}{ }_{t}}{\partial t^{*}{ }_{q t}}$
} 
For the hard-to-observe tasks, switching to gain sharing will reward higher abilities: $\frac{d U_{g}^{*}}{d A_{e}}>\frac{d U^{*}{ }_{p}}{d A_{e}}=0$, but the sorting effects will remain the same if the firm switches to time-rates: $\frac{d U^{*}{ }_{t}}{d A_{e}}=\frac{d U^{*} p}{d A_{e}}=0$

\section{Proof of Proposition 4}

For simplicity, we assume that agent's abilities are the same under the three compensation schemes. ${ }^{18}$

In the batch manufacturing mode with a piece-rate compensation scheme, a simplified profit function of a firm is $\Pi=B^{\text {batch }}(e, q)-\beta-\alpha q$, subject to the maximization of a worker's utility function $U=\beta+\alpha q-D\left(t_{e}, t_{q}\right)$ and the constraint $\beta+\alpha q-D\left(t_{e}, t_{q}\right)>0$, which makes the worker willing to join the firm. Substituting the constraint to the profit function yields $\Pi=B^{\text {batch }}(e, q)-D\left(t_{e}, t_{q}\right)$, with the first order condition being $\frac{\partial}{\partial \alpha}=\left(B_{2}^{\text {batch }}\left(q^{*}\right)-D_{2}\right) \frac{\partial t_{q}}{\partial \alpha}=0$. The maximization of the worker's utility function yields the first order condition $D_{2}=\alpha$. The two first order conditions imply that $\alpha=B_{2}^{\text {batch }}\left(q^{*}\right)$. Thus $D_{2}\left(q^{*}\right)=B_{2}^{\text {batch }}\left(q^{*}\right)$. Suppose $B_{22}^{\text {batch }}<0$ to be a constant. $B_{2}^{\text {batch }}=B_{2}^{\text {batch }}(0)+B_{22}^{\text {batch }} q$. For simplicity, we assume $D_{22}<0$ as a constant. The optimal production volume satisfies $q^{*}=\frac{B_{2}^{\text {batch }}(0)}{D_{22}-B_{22}^{\text {batch }}}$.

\footnotetext{
${ }^{18}$ Note that if we include the change in abilities (i.e. sorting effects), the results of Proposition 4 and Proposition 2 will be strengthened. For Proposition 2, $D_{22}$ and for Proposition 4, $D_{2}{ }^{p}-D_{2}{ }^{t}$ and $D_{2}{ }^{p}-D_{2}{ }^{p}$ characterize how sorting effects help strengthen the results of the two propositions.
} 
In the modern manufacturing mode with time rates and gain sharing, the firm's profit function is $\Pi=(1-\lambda) B^{\text {mod }}(e, q)-\beta$. The maximization of the profit function yields $\frac{\partial}{\partial q}=(1-\lambda) B_{2}^{\text {mod }}=0$. Since the percentage of benefit shared with workers is less than $100 \%$ (i.e. $\lambda<1$ ), the optimal production volume satisfies $B_{2}^{\bmod }(\hat{q})=0$, with $\hat{q}$ being the optimal production volume in modern manufacturing. Since $B_{22}^{\bmod }<0$ is a constant, Taylor series indicate that $B_{2}(\hat{q})=B_{2}^{\bmod }(0)+B_{22}^{\bmod } \hat{q}$. Thus,. $\hat{q}=-\frac{B_{2}^{\bmod }(0)}{B_{22}^{\bmod }}$

$$
q^{*}-\hat{q}=\frac{B_{2}^{\text {batch }}(0)}{D_{22}-B_{22}^{\text {batch }}}+\frac{B_{2}^{\text {mod }}(0)}{B_{22}^{\text {mod }}}
$$

Because of the frequent change in product designs and the costs associated with excessive inventory, one characteristic of modern manufacturing is that $B_{22}^{\bmod }<0$ is much smaller than $B_{22}^{\text {batch }}<0$, because excessive production volume makes profits drop more quickly for modern manufacturers than for batch manufacturers. Specifically, when $B_{22}^{\text {mod }}<\frac{B_{2}^{\text {mod }}(0)}{B_{2}^{\text {batch }}(0)}\left(B_{22}^{\text {batch }}-D_{22}\right)$, the production volume under batch manufacturing and piece rates is larger than under modern manufacturing with time rates or gain-sharing.

\section{Proof of Proposition 5:}

Following the proof for Proposition 1, to obtain analytical results, we approximate costs and benefits with a quadratic approximation around $\hat{q}$.

$$
B(\tilde{q})=B(\hat{q})+B^{\prime}(\hat{q})(\tilde{q}-\hat{q})+\frac{B^{\prime \prime}(\hat{q})}{2}(\tilde{q}-\hat{q})^{2}
$$


After some manipulation, we

have $E\left(B_{t}^{*}-B_{p}^{*}\right)=E\left(B_{g}^{*}-B_{p}^{*}\right)=\left(\frac{-B_{22}}{2}\right) E\left[(\tilde{q}-\hat{q})^{2}\right]$

Notice that the two parts consist of the difference between the quantity produced in piece rates and the quantity produced in time rates/gain sharing: $\tilde{q}-\hat{q}=[\tilde{q}-E(\tilde{q})]+[E(\tilde{q})-\hat{q}]$.

The gap between the actual production and the optimal production volume will be influenced by the uncertainty, $\theta$, i.e., $\tilde{q}-E(\tilde{q})=\eta(\theta)$ with $E[\eta(\theta)]=0$. Let us denote: $s^{2}=E\left[\eta(\theta)^{2}\right]$. Then we have:

$$
E\left(B_{t}^{*}-B_{p}^{*}\right)=E\left(B_{g}^{*}-B_{p}^{*}\right)=\left(\frac{-B_{22}}{2}\right)\left[s^{2}+E(E(\tilde{q})-\hat{q})^{2}\right]
$$

The crucial expression in the above results is $\left(\frac{-B_{22}}{2}\right) s^{2}$, which is greater than zero $\left(B_{22}<0\right)$ and thus means that switching to time rates or gain sharing will always cause the firm's actual output to be closer to its optimal output.

Following the proof for Proposition 2 and 3, we conclude that the outcomes of hard-to-observe tasks, determined by $t_{e}$ and $A_{e}$, are strictly larger under gain sharing and time rates than under piece rates, because

$t_{e}^{t}>t_{e}^{p} \& A_{e}^{t}=A_{e}^{p}=>e^{t}\left(t_{e}^{t}, A_{e}^{t}\right)>e^{p}\left(t_{e}{ }^{p}, A_{e}{ }^{p}\right)$ and $t_{e}^{g}>t_{e}{ }^{p} \& A_{e}^{g}>A_{e}{ }^{p}=>e^{t}\left(t_{e}{ }^{t}, A_{e}{ }^{t}\right)>e^{p}\left(t_{e}{ }^{p}, A_{e}{ }^{p}\right)$. Also, although piece rates produce increased performance on the observable task $t_{q}{ }^{t}<t_{q}{ }^{p} \& A_{q}{ }^{t}<A_{q}{ }^{p}$ and $t_{q}{ }^{g}<t_{q}^{p} \& A_{q}{ }^{g}<A_{q}{ }^{p}$, these increased abilities and effort at observable tasks brings no additional income when they exceed the optimal quantity $\hat{q}$ (i.e. $B_{2}(e, q) \leq 0$ for $q>\hat{q}$ ). Thus, the net income of gain sharing/time rates will be strictly larger than the net income 
under piece rates (i.e., $B_{g}{ }^{*} \geq B_{p}{ }^{*}$ and $B_{t}{ }^{*} \geq B_{p}{ }^{*}$ ), because time rates and gain-sharing yield increased performance on the hard-to-observe task (i.e. $B_{1}(e, q) \geq 0$ for all $e$ ). The combination of this result and the above result of Proposition 1 indicates that

$$
\begin{aligned}
& E\left[B_{t}^{*}\left(e^{t}, \hat{q}\right)\right]-E\left[B_{p}^{*}\left(e^{p}, \tilde{q}\right)\right]>0 \\
& E\left[B_{g}^{*}\left(e^{g}, \hat{q}\right)\right]-E\left[B_{p}^{*}\left(e^{p}, \tilde{q}\right)\right]>0
\end{aligned}
$$

\section{Proof of Proposition 6:}

To minimize costs, the compensation paid byfirms under gain sharing and time rates (i.e. $L_{t}$ and $L_{g}$ ) will be set equal to the disutility of effort, that is, $L_{t}=L_{g}=D\left(\hat{t}_{e}, \hat{t}_{q}\right)$, and $\hat{t}_{e}+\hat{t}_{p} \leq T$, with $T$ being the total time at work. By contrast, to motivate the employees to devote the desired level of effort, the piece rate is set as the marginal disutility of effort, that is, $\alpha=D_{2}\left(\hat{t}_{e}, \hat{t}_{q}\right)$. Since the marginal disutility increases as the firms' required effort increases, (i.e. $D_{22}>0$ ), piece rates generate more pay for the agent, because $D_{2} \hat{t}_{q}=\int_{0}^{\hat{t}_{q}} D_{2}\left(\hat{t}_{e}, \hat{t}_{q}\right) d t_{q}>\int_{0}^{\hat{t}_{q}} D_{2}\left(\hat{t}_{e}, t_{q}\right) d t_{q}=D\left(\hat{t}_{q}\right)$, with $D_{2}\left(\hat{t}_{e}, \hat{t}_{q}\right)$ being a constant while $D_{2}\left(\hat{t}_{e}, t_{q}\right)$ being an increasing function of $t_{q}$. This indicates that the labor cost for doing observable tasks under piece rates is higher than that of time rates and gain sharing. In other words, if we only consider simple and observable tasks, time-rates and gain-sharing provide employees with minimal rents, while piece-rates provide more rents for employees.

For the hard-to-observe tasks, suppose $w$ to be the total income under any of the compensation schemes. To make workers devote $\hat{t}_{e}$ amount of effort to hard-to-observe 
tasks, total worker income must satisfy $w=\frac{D_{1}\left(\hat{t}_{e}, \hat{t}_{q}\right)+D_{2}\left(\hat{t}_{e}, \hat{t}_{q}\right) \frac{\partial t_{q}}{\partial t_{e}}}{p^{\prime}\left(\hat{t}_{e}\right)}$. The equation indicates that the workers' total income depends on the marginal disutility of the optimal effort allocation and the observability of the hard-to-observe task $p^{\prime}\left(\hat{t}_{e}\right)$. The harder it is to observe and the higher the desired level of effort on the hard to observe task, which depends on its marginal contribution to the firm's benefit function, the higher the worker's total income is.

$$
\text { If } w=\frac{D_{1}\left(\hat{t}_{e}, \hat{t}_{q}\right)+D_{2}\left(\hat{t}_{e}, \hat{t}_{q}\right) \frac{\partial t_{q}}{\partial t_{e}}}{p^{\prime}\left(\hat{t}_{e}\right)}>D_{2} \hat{t}_{q} \text {, the labor costs will be equal under the }
$$
three compensation schemes $L^{p}=L^{g}=L^{t}$. Because to induce workers to devote large amount of effort to hard-to-observe tasks (i.e. a higher $D_{1}\left(\hat{t}_{e}, \hat{t}_{q}\right)$ ), the firms need to pay large amount of total compensation, which exceeds the rent from piece-rate and makes the total wages of the three compensation schemes equal. But if $w=\frac{D_{1}\left(\hat{t}_{e}, \hat{t}_{q}\right)+D_{2}\left(\hat{t}_{e}, \hat{t}_{q}\right) \frac{\partial t_{q}}{\partial t_{e}}}{p^{\prime}\left(\hat{t}_{e}\right)}<D_{2} \hat{t}_{q}$, which indicates that the required level of hard-toobserve tasks is low (i.e. a lower $D_{1}\left(\hat{t}_{e}, \hat{t}_{q}\right)$ ), the labor costs of piece rates will be strictly higher than those of time rates or gain sharing (i.e. $L^{p}>L^{g}$ and $L^{p}>L^{t}$ ).

In conclusion, the labor costs of piece rates are no less than the labor costs of time rates or gain sharing. $L^{p} \geq L^{g}$ and $L^{p} \geq L^{t}$. 


\section{Proof of Proposition 7:}

To contrast profits under the different compensation schemes, we need to examine the following:

$$
\begin{aligned}
& E\left(\Pi_{t}^{*}-\Pi_{p}^{*}\right)=E\left(B_{t}^{*}(\hat{q})-B_{p}^{*}(\tilde{q})\right)+E\left(L^{p}-L^{t}\right) \\
& E\left(\Pi_{g}^{*}-\Pi_{p}^{*}\right)=E\left(\left(B_{g}^{*}(\hat{q})-B_{p}^{*}(\tilde{q})\right)+E\left(L^{p}-L^{g}\right) .\right.
\end{aligned}
$$

Proposition 5 indicates that if Just-In-Time and hard-to-observe tasks are valuable to a firm, $E\left[B_{t}^{*}\left(e^{t}, \hat{q}\right)\right]-E\left[B_{p}^{*}\left(e^{p}, \tilde{q}\right)\right]>0$ and $E\left[B_{g}^{*}\left(e^{g}, \hat{q}\right)\right]-E\left[B_{p}^{*}\left(e^{p}, \tilde{q}\right)\right]>0$.

Proposition 6 indicates that $L^{p} \geq L^{g}$ and $L^{p} \geq L^{t}$. In conclusion, Proposition 5 and Proposition 6 imply that $E\left(\Pi_{t}^{*}-\Pi_{p}^{*}\right)>0$ and $E\left(\Pi_{g}^{*}-\Pi_{p}^{*}\right)>0$. 